\title{
Subsidence, stress regime and rotation(s) of a tectonically active sedimentary basin within the western Alpine Orogen: the Tertiary Piedmont Basin (Alpine domain, NW Italy)
}

\author{
B. CARRAPA ${ }^{1}$, G. BERTOTTI ${ }^{1} \&$ W. KRIJGSMAN ${ }^{2}$ \\ ${ }^{1}$ Vrije Universiteit, Faculty of Earth and life Sciences, De Boelelaan 1085, \\ 1081 HV Amsterdam, The Netherlands (e-mail: carb@geo.vu.nl) \\ ${ }^{2}$ Utrecht University, Paleomagnetic Laboratory 'Fort Hoofddijk', \\ Faculty of Earth Sciences, Budapestlaan 17, \\ 3584 CD Utrecht, The Netherlands
}

\begin{abstract}
The Oligocene to Miocene Tertiary Piedmont Basin (TPB) is located in the NW part of Italy at the junction between the Apennine and the Alpine thrust belts. The position of the TPB on top of the Alpine/Apennine Orogen poses fundamental questions as to the tectonics of the basin subsidence. Having undergone little deformation, the TPB sediments provide an insight into the stress regime and rotations in the kinematically very complex area surrounding the basin itself. In this study we integrate subsidence and structural analysis with measurements of magnetic susceptibility anisotropy (AMS) and natural remanent magnetization (NRM) in order to better constrain the tectonic kinematics of the basin evolution. A major important period of subsidence occurred in the Middle Miocene involving the whole basin. During this period the TPB experienced NE-SW-directed compression and limited shortening. Some NW-SE-directed compressional features have been identified and they were probably active during post Tortonian times. Structures associated with north-south tension are quite common, but the amount of strain that they accommodate is minor. In addition this research provides new preliminary data suggesting counterclockwise rotation in the TPB by $c .20^{\circ}$ which has taken place during Middle Miocene time.
\end{abstract}

The presence of strongly subsiding areas inside and overlying orogenic arcs is at the same time a common observation and a typically unexplained phenomenon. In Europe, two apparent examples are the Transylvania Basin, lying within the East Carpathian-South Carpathian Arc (e.g. Ciulavu \& Bertotti 1994; Huismans et al. 1997; Matenco \& Bertotti 2000), and the western Po Plain situated between the Western Alps and the Ligurian Alps. Both basins formed during and/or following deformation in the surrounding orogenic belt and are characterized by a surprisingly low amount of internal deformation. A discrepancy between the amount of subsidence and the paucity of tectonic deformation is apparent, thereby leaving open the question as to the cause of the observed subsidence.

The Tertiary Piedmont Basin (TPB), a wellexposed part of the western Po Plain (Fig. 1) is well suited for the purpose of investigating the indicated topics. The basin, which has a $>4 \mathrm{~km}$ thick Lower Oligocene to Upper Miocene fill is located on the strongly shortened area of the Alpine-Apennine junction (Fig. 1). The TPB is particularly interesting because its most important features, such as the kinematics and dynamics of subsidence and the structural setting under which the accommodation space was created, have never been addressed at a basin scale. The TPB also plays a very significant role in the regional geological picture, since it overlies and seals Alpine and Apennine structures. The stress/strain evolution of the basin contains important information on this key area. The TPB has been chosen because of the wellpreserved Oligo-Miocene clastic infill and the relatively good stratigraphic control of the sedimentary record. Because of the Pliocene and younger uplift (e.g. Lorenz 1984), basin sediments are presently lying at elevations of several hundred metres and are dissected by fairly deep valleys providing comparatively good outcrops. 

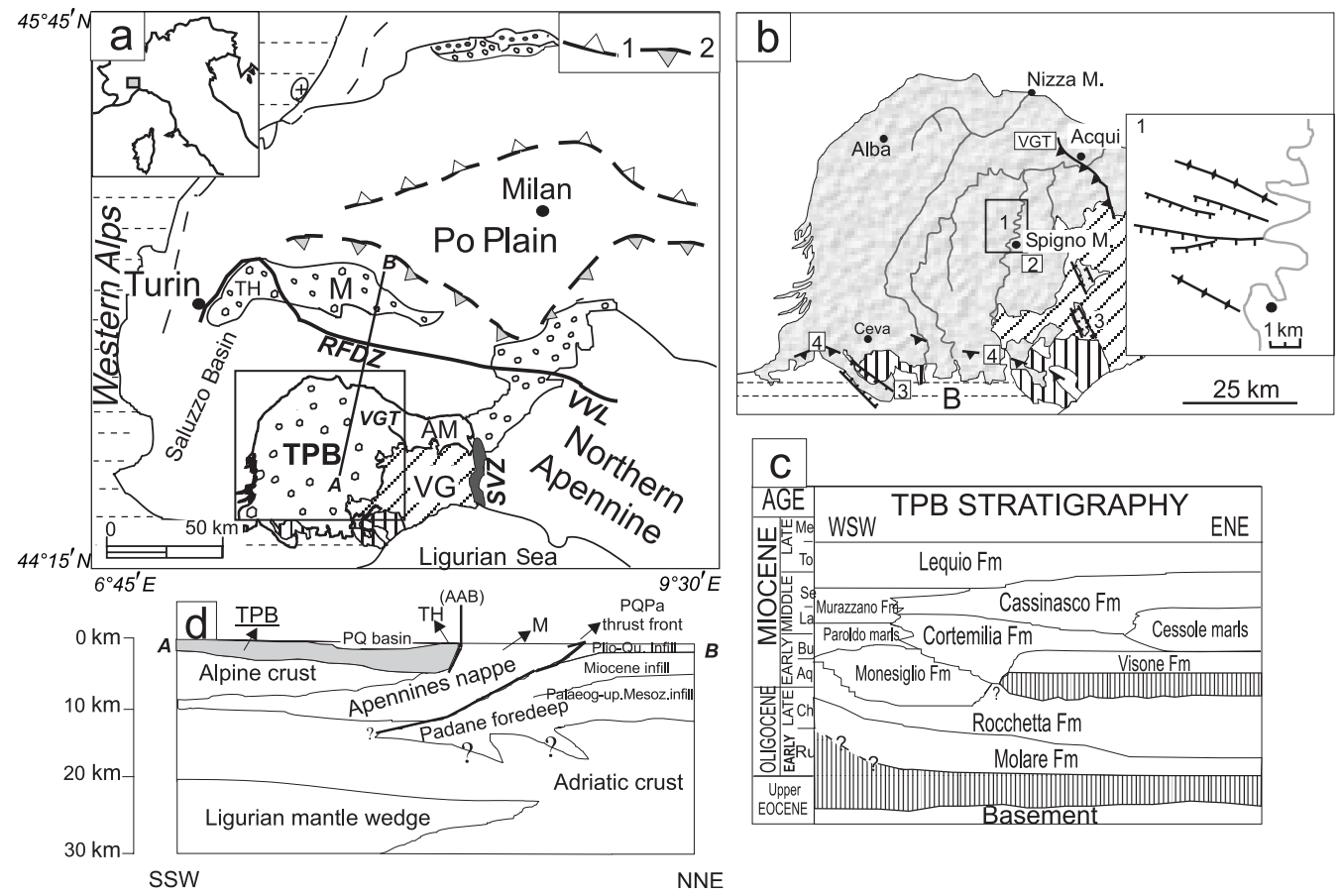

Fig. 1. (a) Tectonic map of NW Italy modified from Polino et al. (1995); 1, Apenninic thrusts, 2, South Alpine Thrusts. Square, study area; black vertical lines, Hercynian Crystalline Massifs; black close dots, Cretaceous to Eocene flysch; open dots, Oligo-Miocene sediments. TPB, Tertiary Piedmont Basin; AM, Alto Monferrato; TH, Torino Hill; M, Monferrato; VG, Voltri Group; RFDZ, Rio Freddo deformation zone; VVL, Villalvernia-Varzi Line; SVZ, Sestri Voltaggio Zone; VGT, Val Gorrini Thrust; (b) detailed enlargement of the study area with structural features mentioned in the text: (1) folds and faults described by Gelati \& Gnaccolini (1998); (2) the area studied by Bernini \& Zecca (1990) (Mioglia fold) and Mutti et al. (1995) (NE-SW trending normal faults). Note that the small scale $(c .2 \mathrm{~km})$ of the latter structures does not allow direct visualization in Fig. 1(b); $\mathrm{B}=$ Briançonnais domain; (3) Oligocene grabens by Lorenz (1979); (4) thrusts found inside the magnetic basement after Cassano et al. (1986). (c) stratigraphic scheme modified after Gelati (1968). (d) Structural profile after Clari et al. (1995) (M, Monferrato; PQ basin, Plio-Quaternary basin; PQPa thrust front, Plio-Quaternary Padan thrust front).

In this contribution, we report on three fundamental issues, the subsidence, the stress/strain history and tectonic rotation(s) of the basin. To reconstruct the subsidence history we build on the vast stratigraphic and sedimentological database from the literature (Gelati 1968; Gnaccolini et al. 1990; Gelati et al. 1993; Gnaccolini \& Rossi 1994; Gelati \& Gnaccolini 1996; Gelati \& Gnaccolini 1998). We here derive the stress/strain regime during and following subsidence using structural analysis and, for the first time in the TPB, anisotropy of magnetic susceptibility (AMS) and natural remanent magnetization (NMR). Taking advantage of the low degree of internal deformation we furthermore derive information on possible rotations of the TPB. The final aim of this study is a better understanding of the TPB geodynamic evolution through a multidisciplinary approach.

\section{Geological setting of the Tertiary Piedmont Basin}

The Tertiary Piedmont Basin (TPB) is an episutural basin formed on top of the Mesoalpine edifice resulting from the collision between the Adriatic and the European plates (Rehault et al. 1985; Polino et al. 1990; Schumacher \& Laubscher 1996; Biella et al. 1997; Schmid \& Kissling 2000). The basin developed on a substratum consisting of allochthonous Alpine and Apennine units (Roure et al. 1990; Dela Pierre et al. 1995; Piana \& Polino 1995; Piana 2000). The present day southern and south- 
western limits of the TPB sediments are of an erosional nature and, consequently, it is unknown how far the basin extended above the Ligurian Alps. Towards the north, the Oligo-Miocene sediments of the TPB dip underneath the younger clastic sediments of the western Po Plain (Dalla et al. 1992; Schumacher \& Laubscher 1996).

\section{Sedimentological and structural evolution}

During the Late Eocene-Early Oligocene, a prograding marine transgression, probably coming from the north-NE (Lorenz 1979; Lorenz 1984; Gelati \& Gnaccolini 1988), followed by a progressive deepening of the basin floor, took place in the TPB. As a result, alluvial and nearshore sediments were deposited (i.e. the Molare Formation) (Lorenz 1979; Lorenz 1984; Gelati et al. 1993; Gelati \& Gnaccolini 1996; Gelati \& Gnaccolini 1998). Sediments of the Molare Formation show a clear source in the southern sector (present day Ligurian Alps and Voltri Group) (Gelati \& Gnaccolini 1982). During the deposition of the Molare Formation, limited extension was taking place (Lorenz 1984; Hoogerduijn Strating et al. 1991; Hoogerduijn Strating 1994; Vanossi et al. 1994; Mutti et al. 1995).

At the end of the Early Oligocene, an increase in subsidence (Dela Pierre et al. 1995) was coeval with the deposition of a marly/sandy sequence known as the Rocchetta Formation (shallowwater sandstones and hemipelagic mudstones; Late Oligocene-Early Miocene). The transition between the alluvial and nearshore deposits of the Molare Formation and the overlying Rocchetta Formation marks a general deepening of the basin during the Oligocene and Early Miocene. Palaeocurrent indicators document sediment transport mainly from the SSW (present-day Ligurian Alps and Voltri Group) towards the NNE (Gelati et al. 1993). The contact between the Molare Formation and the Rocchetta Formation is progressively younger from NE to SW (Fig. 1c).

Evidence of shortening has been detected during Late Oligocene-Early Miocene times. A contractional structure (Mioglia fold) with NE-SW direction of shortening was active until Burdigalian times in the southern sector of the study area (Cazzola \& Rigazio 1982; Bernini \& Zecca 1990) (Fig. 1b). Some NW-SE to NNWSSE-trending folds active in Late Oligocene times have been observed in the central-eastern part of the study area (Gelati \& Gnaccolini 1998) (Fig. 1b). Northeast-southwest shortening during post-Oligocene times also formed the Val Gorrini Thrust (VGT) (Piana et al. 1997; Fig. 1a) across which the metamorphic rocks of the Voltri Group are thrust on to the Oligocene sediments of the TPB. The VGT deformation is sealed by the Lower Miocene Visone Formation (Capponi et al. 1999).

Some ENE-WSW normal faults, with displacements up to few hundred metres, have been described as being active during the deposition of the Rocchetta Formation, but with poor time constraints (Bernini \& Zecca 1990; Mutti et al. 1995) (Fig. 1b).

During the Early Miocene, small platforms with both terrigenous and carbonate sedimentation developed in the eastern part of the basin while the central part was characterized by more widespread basinal conditions. Hemipelagic sediments characterize the NW area. The whole central area was characterized by silty/sandy sequences within which several different depositional bodies can be distinguished on the basis of the silt/sand ratio (Rocchetta-Monesiglio Group; see Gelati \& Gnaccolini 1998). In the central-eastern part of the study area, normal faults directed west-east/WNW-ESE were active during Aquitanian-Burdigalian times (Gelati \& Gnaccolini 1998) (Fig. 1b).

Since Late Burdigalian times, sedimentation became more homogeneous in the entire basin with the deposition of the Cortemilia Formation (classic turbidites with a flow direction from west to east) (Gelati et al. 1993). The homogeneity of Miocene palaeocurrent directions suggests a change/enlargement in the sediment source area (Gelati et al. 1993; Carrapa et al. 2000). This change is also supported by sandstone composition patterns which record an increase of rock fragments derived from quarzites, mica schists and gneisses, and a decrease in the percentage of rock fragments derived from ultramafic rocks (Gnaccolini \& Rossi 1994; Gelati \& Gnaccolini 1998).

During Langhian/Serravallian times the eastern part of the TPB was characterized by shallow-water shelf sedimentation (Caprara et al. 1985; Ghibaudo et al. 1985) while in the rest of the basin sedimentation was characterized by homogeneous deep-water tabular turbidites (Cassinasco Formation, Murazzano Formation, Lequio Formation) (Gelati et al. 1993).

\section{Subsidence analysis \\ Method and input data}

To derive the history of vertical movements in the TPB we have constructed subsidence curves from different localities within the basin (Figs 2 \& 3). For its central and southern parts we have used a published stratigraphic reconstruction 

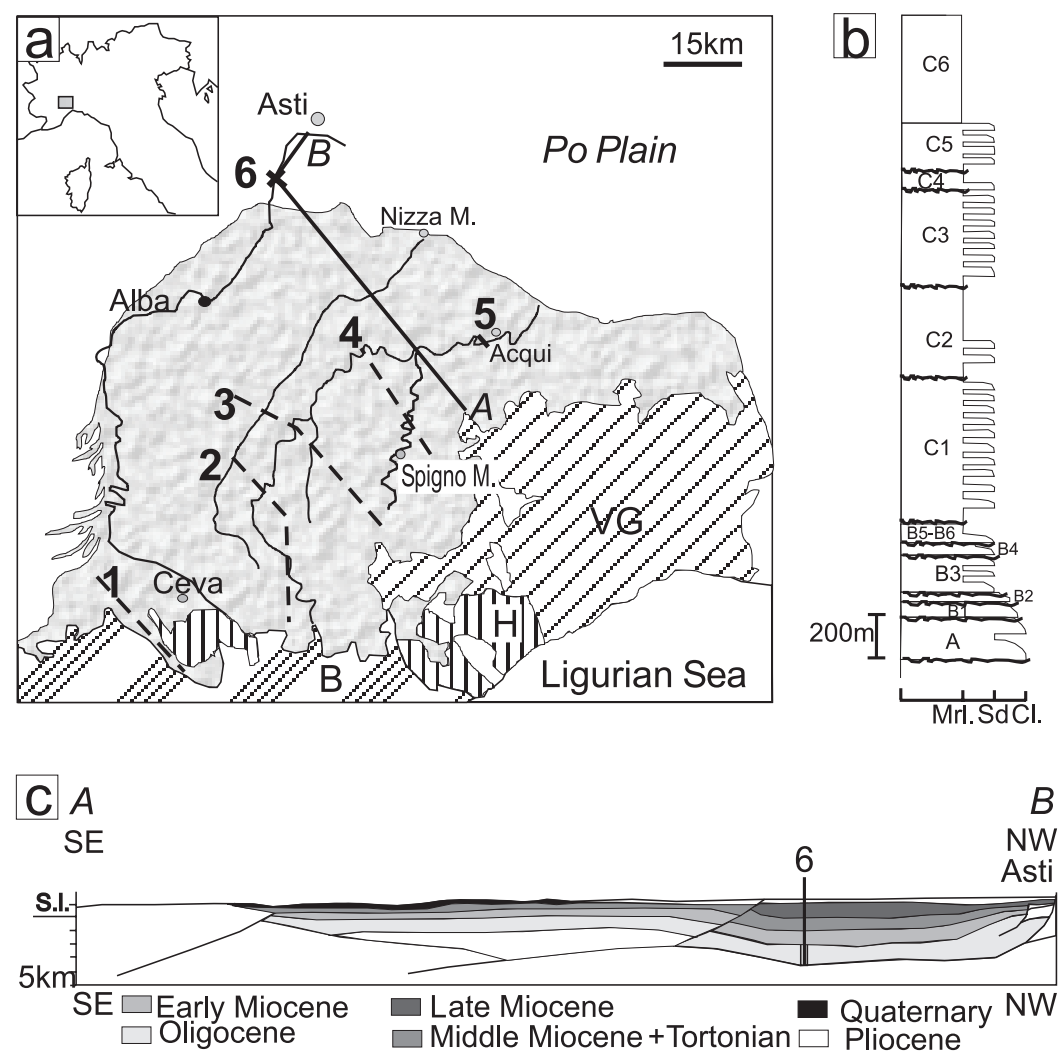

Fig. 2. (a) Map with location of the sections used for the stratigraphic reconstruction of Gelati et al. (1993) and of profile 2 from Pieri \& Groppi (1981) used to construct the subsidence analysis in Fig. 3 (the cross corresponds with the synthetic well on which the subsidence curve 6 of Fig. 3 is based); B, Briançonnais domain; H, Hercynian Crystalline Massifs; VG, Voltri Group. (b) schematic lithostratigraphic column corresponding with section 4 in Figure 3 (Mrl, marls, Sd, sandstones, $\mathrm{Cl}$, conglomerates); (c) Profile $A-B$ after Cassano et al. (1986).

obtained by assembling stratigraphic sections along several $\mathrm{km}$ long transects (Gelati et al. 1993; Figs 2a \& 2b). Given the gentle dip of the bedding, this was the only way to cover reasonably wide stratigraphic intervals. In the northern part of the basin we have extracted a synthetic stratigraphic column from an interpreted seismic line (plate II, line 2 from Pieri \& Groppi (1981) interpreted by Cassano et al. (1996)) (Fig. 2a). In this region (section 6, Tanaro) the TPB kept on subsiding into postMiocene times and was thus buried by Pliocene to Quaternary sediments (Figs 2a \& 3). Lithologies and palaeobathymetries have been obtained from regional correlations (Gelati et al. 1993) (Table 1). Average palaeodepths between 25 and $50 \mathrm{~m}$ have been chosen for the Molare Formation due to its sedimentological features which indicate a shallow water and transitional environment. Palaeobathymetries for younger formations are based on the occurrence of particular benthonic foraminifer and on planktonic/benthonic species ratios indicating palaeodepths between 200 and $600 \mathrm{~m}$ for Upper Oligocene-Upper Miocene sediments (Gelati et al. 1993). We ended our analysis in Tortonian times (except for section 6) in order to avoid the uncertainties associated with the Messinian crisis. Stratigraphic columns have been backstripped adopting standard procedures (Sclater \& Christie 1980; Bond \& Kominz 1984; Bessis 1986). Subsidence curves describe the vertical movements of the basement and of the formational boundaries (chronostratigraphic horizons), taking into account compaction. To enable easier visualization of changes in vertical movements occurring during basin evolution, we have also constructed subsidence rate diagrams (Fig. 4). 

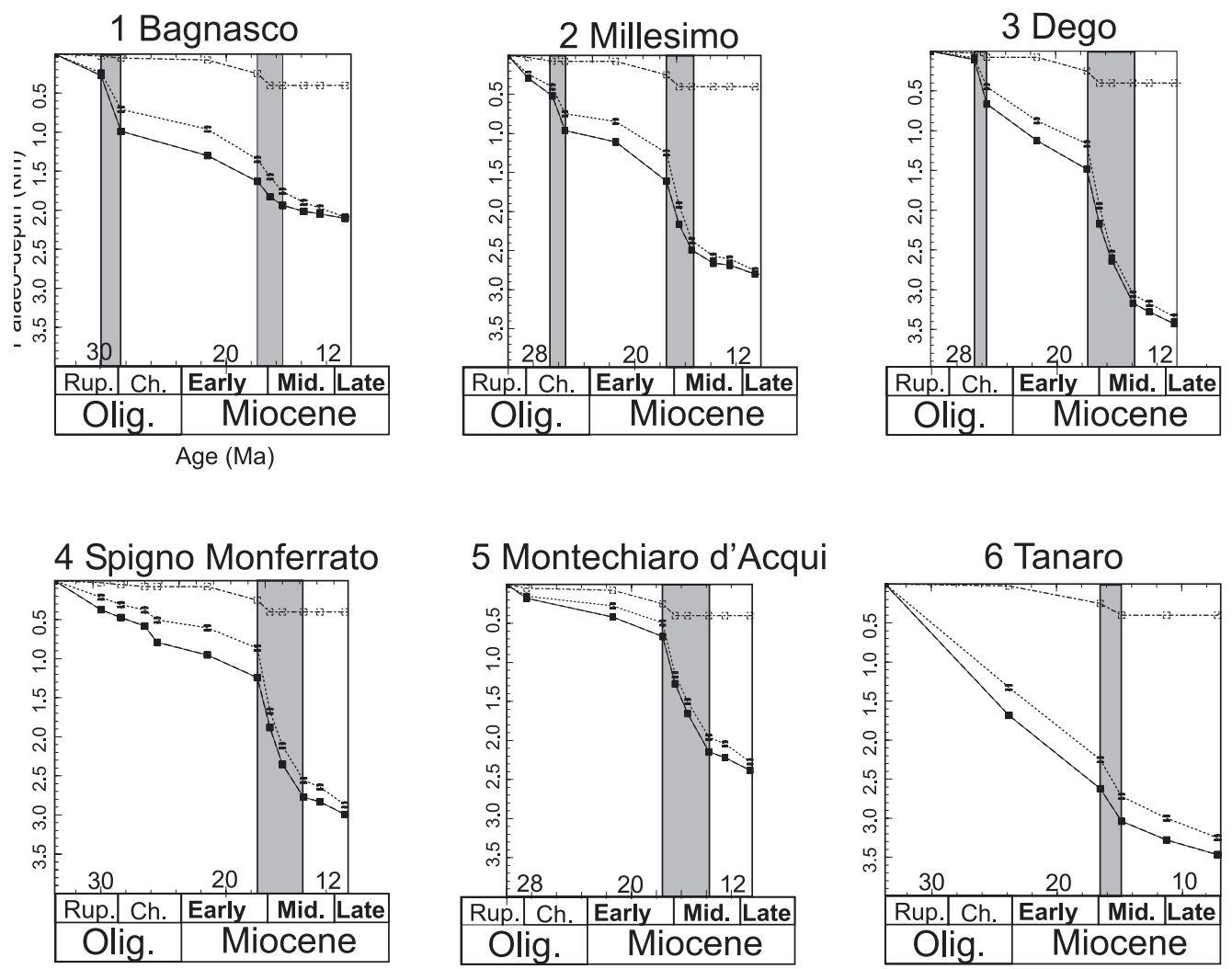

$-\cdot-\cdot-$ Water depth

. Min. basement sub.

Max.basement sub.

Fig. 3. Subsidence curves for the TPB. Note that section 6 shows a fairly constant subsidence through the whole Oligocene, probably due to poor stratigraphic control of the section, which does not allow the detection of accelerating subsidence during this time-span. Grey bars indicate times when the most subsidence occurred.

\section{Results}

Subsidence of the TPB began in the Early Oligocene and continued throughout the Miocene (Figs 3 \& 4). During the Oligocene, subsidence was stronger in the SW part of the TPB (Bagnasco, Millesimo, Dego; Fig. 3) than in the NE (Montechiaro d'Acqui; Fig. 3), where little movement took place.

Towards the end of the Early Miocene, subsidence accelerated over most of the TPB, including the eastern sector which was a high structural domain during the Oligocene. Burdigalian subsidence affected the entire basin and, in particular, its central-eastern parts (Dego, Spigno, Montechiaro d'Acqui; Fig. 3). Magnitudes of vertical movements are higher in this period than during Oligocene time $(<1 \mathrm{~km}$ during the Oligocene, $>2 \mathrm{~km}$ during the Miocene).
A compilation of subsidence rates along the selected transects shows (Fig. 4) that the main periods of subsidence are restricted to a remarkably short time span $(\geq 1 \mathrm{~mm} /$ year between 17.5 and $15.5 \mathrm{Ma}$ and $<0.5 \mathrm{~mm} /$ year after 17.5 Ma). The central part of the basin (Dego, Spigno) remains the most subsiding area from Chattian until Burdigalian-Langhian times, with relatively high subsidence rates from $0.7 \mathrm{~mm} /$ year during the Chattian up to $\geq 1 \mathrm{~mm} /$ year during the Burdigalian-Langhian. The northeastern part of the basin was not strongly affected by the Rupelian subsidence, although it was strongly subsiding during the Langhian. This because of compressional tectonics active in the eastern sector until Late Aquitanian times and responsible for the uplift and erosion of the Rocchetta sediments (Piana et al. 1997). 
Table 1. Input data used to construct the subsidence curves of Figure 3

Deph Age Sand Silt Shale Carbonate Halite Anhydr. W.D. min W.D. max Aver. W.D.

\section{Bagnasco}

\section{C6}

$\mathrm{C} 5$

$\mathrm{C} 4$

C3

$\mathrm{C} 2$

C1

$\mathrm{B} 5+\mathrm{B} 6$

A

A

$\begin{array}{cccc}28 & 10.5 & 0 & 0 \\ 143 & 12.5 & 0.8 & 0 \\ 214 & 13.8 & 0.8 & 0 \\ 357 & 15.5 & 0.5 & 0 \\ 543 & 16.5 & 0.5 & 0 \\ 614 & 17.5 & 0 & 0 \\ 828 & 21.5 & 0 & 0 \\ 1057 & 28.4 & 0 & 0 \\ 1500 & 30 & 0 & 0 \\ 1714 & 33.7 & 1 & 0 \\ 1715 & 0 & 1 & 0\end{array}$

\section{Millesimo}

\section{C6}

C5

C4

C3

C2

C1

B5+B6

B4

B3

B2

B1

$\begin{array}{cccc}128 & 10.5 & 0 & 0 \\ 280 & 12.5 & 0.7 & 0 \\ 314 & 13.8 & 0.8 & 0 \\ 514 & 15.5 & 0.6 & 0 \\ 971 & 16.5 & 0.8 & 0 \\ 1486 & 17.5 & 0.8 & 0 \\ 1714 & 21.5 & 0.2 & 0 \\ 1814 & 25.5 & 0.2 & 0 \\ 2157 & 26.5 & 0.5 & 0 \\ 2271 & 28.4 & 0.5 & 0 \\ 2485 & 30 & 1 & 0 \\ 2486 & 0 & 1 & 0\end{array}$

1
0.2
0.2
0.5
0.5
1
1
1
1
0
0

0
0
0
0
0
0
0
0
0
0
0

$\begin{array}{ccc}0 & 0 & 200 \\ 0 & 0 & 200 \\ 0 & 0 & 200 \\ 0 & 0 & 200 \\ 0 & 0 & 200 \\ 0 & 0 & 200 \\ 0 & 0 & 100 \\ 0 & 0 & 50 \\ 0 & 0 & 0 \\ 0 & 0 & 0 \\ 0 & 0 & 0\end{array}$

$\begin{array}{cc}600 & 400 \\ 600 & 400 \\ 600 & 400 \\ 600 & 400 \\ 600 & 400 \\ 600 & 400 \\ 400 & 250 \\ 100 & 75 \\ 100 & 50 \\ 50 & 25 \\ 0 & 0\end{array}$

\section{Dego}

$\begin{array}{lcccc}\text { C6 } & 314 & 10.5 & 0.5 & 0 \\ \text { C5 } & 485 & 12.5 & 1 & 0 \\ \text { C4 } & 600 & 13.8 & 0.8 & 0 \\ \text { C3 } & 1114 & 15.5 & 0.8 & 0 \\ \text { C2 } & 1714 & 16.5 & 1 & 0 \\ \text { C1 } & 2342 & 17.5 & 1 & 0 \\ \text { B5+B6 } & 2454 & 21.5 & 0 & 0 \\ \text { B4 } & 2886 & 25.5 & 0.8 & 0 \\ \text { B3 } & 3200 & 26.5 & 0.5 & 0 \\ \text { B1+B2 } & 3257 & 30 & 1 & 0 \\ & 3257.1 & 01 & 0 & 0\end{array}$

1
0.3
0.2
0.4
0.2
0.2
0.8
0.8
0.5
0.5
0
0

0
0
0
0
0
0
0
0
0
0
0
0

$\begin{array}{ccc}0 & 0 & 200 \\ 0 & 0 & 200 \\ 0 & 0 & 200 \\ 0 & 0 & 200 \\ 0 & 0 & 200 \\ 0 & 0 & 200 \\ 0 & 0 & 100 \\ 0 & 0 & 50 \\ 0 & 0 & 50 \\ 0 & 0 & 50 \\ 0 & 0 & 0 \\ 0 & 0 & 0\end{array}$

$\begin{array}{cc}600 & 400 \\ 600 & 400 \\ 600 & 400 \\ 600 & 400 \\ 600 & 400 \\ 600 & 400 \\ 400 & 250 \\ 100 & 75 \\ 100 & 75 \\ 100 & 75 \\ 50 & 25 \\ 0 & 0\end{array}$

\section{Spigno M.}

\begin{tabular}{lccccccccccc} 
C6 & 343 & 10.5 & 0.5 & 0 & 0.5 & 0 & 0 & 0 & 200 & 600 & 400 \\
C5 & 571 & 12.5 & 1 & 0 & 0 & 0 & 0 & 0 & 200 & 600 & 400 \\
C4 & 657 & 13.8 & 0.8 & 0 & 0.2 & 0 & 0 & 0 & 200 & 600 & 400 \\
C3 & 1100 & 15.5 & 0.8 & 0 & 0.2 & 0 & 0 & 0 & 200 & 600 & 400 \\
C2 & 1543 & 16.5 & 0.4 & 0 & 0.6 & 0 & 0 & 0 & 200 & 600 & 400 \\
C1 & 2200 & 17.5 & 1 & 0 & 0 & 0 & 0 & 0 & 200 & 600 & 400 \\
B5+B6 & 2286 & 21.5 & 0.2 & 0 & 0.8 & 0 & 0 & 0 & 100 & 400 & 250 \\
B4 & 2385 & 25.5 & 0 & 0 & 1 & 0 & 0 & 0 & 50 & 100 & 75 \\
B3 & 2514 & 26.5 & 0.2 & 0 & 0.8 & 0 & 0 & 0 & 50 & 100 & 75 \\
B2 & 2557 & 28.4 & 0 & 0 & 1 & 0 & 0 & 0 & 50 & 100 & 75 \\
B1 & 2628 & 30 & 1 & 0 & 0 & 0 & 0 & 0 & 0 & 100 & 50 \\
A & 2814 & 33.7 & 0.4 & 0 & 0.6 & 0 & 0 & 0 & 0 & 50 & 25 \\
& 2815 & 0 & 0.4 & 0 & 0.6 & 0 & 0 & 0 & 0 & 0 & 0 \\
\hline
\end{tabular}


Table 1 (continued)

\begin{tabular}{|c|c|c|c|c|c|c|c|c|c|c|c|}
\hline & Deph & Age & Sand & Silt & Shale & Carbonate & Halite & Anhydr. & W.D. min & W.D. max & Aver. W.D. \\
\hline \multicolumn{12}{|c|}{ Montechiaro d'Acqui } \\
\hline C6 & 343 & 10.5 & 0.5 & 0 & 0.5 & 0 & 0 & 0 & 200 & 600 & 400 \\
\hline $\mathrm{C} 5$ & 571 & 12.5 & 1 & 0 & 0 & 0 & 0 & 0 & 200 & 600 & 400 \\
\hline $\mathrm{C} 4$ & 657 & 13.8 & 0.8 & 0 & 0.2 & 0 & 0 & 0 & 200 & 600 & 400 \\
\hline $\mathrm{C} 3$ & 1114 & 15.5 & 0.8 & 0 & 0.2 & 0 & 0 & 0 & 200 & 600 & 400 \\
\hline $\mathrm{C} 2$ & 1457 & 16.5 & 0.4 & 0 & 0.6 & 0 & 0 & 0 & 200 & 600 & 400 \\
\hline $\mathrm{C} 1$ & 1971 & 17.5 & 1 & 0 & 0 & 0 & 0 & 0 & 200 & 600 & 400 \\
\hline $\mathrm{B} 5+\mathrm{B} 6$ & 2014 & 21.5 & 0.2 & 0 & 0.8 & 0 & 0 & 0 & 100 & 400 & 250 \\
\hline $\mathrm{B} 2-\mathrm{B} 4$ & 2114 & 28.4 & 0 & 0 & 1 & 0 & 0 & 0 & 50 & 100 & 75 \\
\hline \multirow[t]{2}{*}{ A } & 2214 & 30 & 1 & 0 & 0 & 0 & 0 & 0 & 0 & 100 & 50 \\
\hline & 2215 & 0 & 0.4 & 0 & 0.6 & 0 & 0 & 0 & 0 & 0 & 0 \\
\hline \multicolumn{12}{|l|}{ Tanaro } \\
\hline Pliocene & 410 & 5.3 & 0.2 & 0 & 0.8 & 0 & 0 & 0 & 50 & 100 & 75 \\
\hline Messinian & 550 & 7.12 & 0.5 & 0 & 0.5 & 0 & 0 & 0 & 50 & 100 & 75 \\
\hline Tortonian & 800 & 11.2 & 0.5 & 0 & 0.5 & 0 & 0 & 0 & 200 & 600 & 400 \\
\hline Serravallian & 1080 & 14.8 & 0.5 & 0 & 0.5 & 0 & 0 & 0 & 200 & 600 & 400 \\
\hline Langhian & 1400 & 16.5 & 0.5 & 0 & 0.5 & 0 & 0 & 0 & 200 & 600 & 400 \\
\hline Aquitanian & 2100 & 23.8 & 0.5 & 0 & 0.5 & 0 & 0 & 0 & 50 & 400 & 225 \\
\hline \multirow[t]{2}{*}{ Oligocene } & 3400 & 33.7 & 0.5 & 0 & 0.5 & 0 & 0 & 0 & 0 & 50 & 25 \\
\hline & 3400.1 & 0 & 0.5 & 0 & 0.5 & 0 & 0 & 0 & 0 & 0 & 0 \\
\hline
\end{tabular}

First column, sequences from Gelati et al. (1993) and Pieri \& Groppi (1981). Age, chronological boundaries; w.d. max, maximum palaeodepth; w.d. min, minimum palaeodepth; aver. w.d., average between w.d. max and w.d. $\min$.

\section{Subsidence rates}

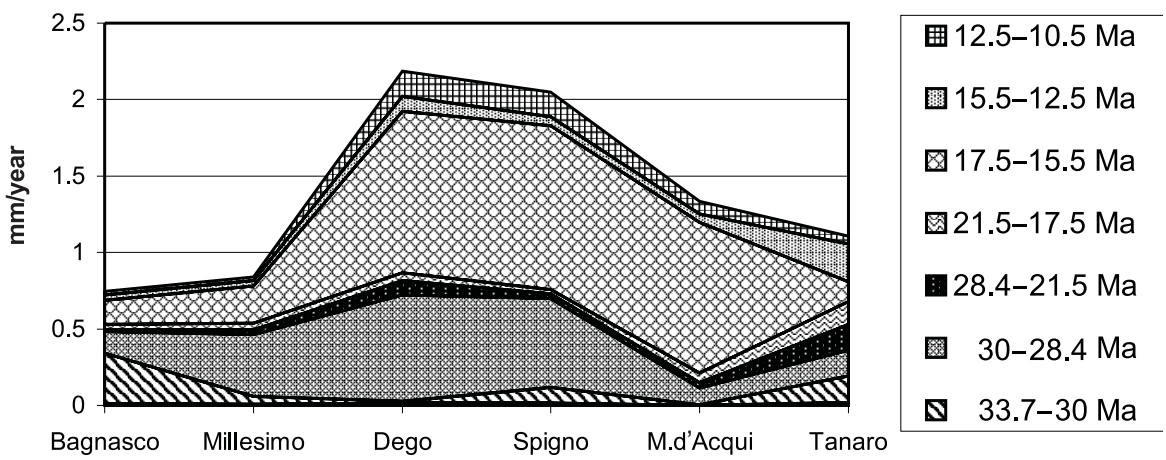

Stratigraphic sections

Fig. 4. Early Oligocene-Late Miocene subsidence rates based on data obtained from the subsidence analysis of Fig. 3.

\section{Structural studies}

The occurrence of a $>4 \mathrm{~km}$ deep basin within an area of convergence and more interestingly overlapping an orogenic wedge, poses major questions as to the tectonic mechanism responsible for the observed subsidence. An apparent feature of the TPB is the lack of major tectonic structures. For instance, normal faults never show offsets larger than few hundred metres. Given the long history of investigations in the area, it is also unlikely 
that major structures have escaped field mapping. Smaller-scale structural features such as folds and faults ranging from several tens of meters to decimetres, on the contrary, are not uncommon in the TPB and have received surprisingly little attention. Despite the limited strain that they accommodate, these structures are of great importance because they constrain the stress regime during basin development. A determination of the stress regime during subsidence is obviously a necessary first step to understand the subsidence dynamics of the TPB.

\section{Method and input data}

Two approaches have been used to reconstruct the stress evolution of the TPB, classical structural analysis on folds and faults, and palaeostress analysis. In the first case, outcropscale structures have been described and measured to derive fold axes and transport directions in the case of asymmetrical folds and of thrusts. Contractional axes are considered to be perpendicular to the fold axes and parallel to the transport directions.

When enough faults were present in a single outcrop, we carried out a palaeostress analysis following well-established principles (Angelier, 1989 and references therein). To determine the position and shape of the stress tensor we have used the program TENSOR (Delvaux, 1993). Measurements were taken generally on subhorizontal beds. The typical problem in reconstructing the stress evolution of a sedimentary basin is the dating of single tectonic structures. In some important cases we were able to date folds and faults on the basis of their synsedimentary character. These structures are described in detail in the following section. For other features, a minimum age has been derived from the age of the sediments affected by deformation. A similar approach has been used for the palaeostress measurements.

\section{Results}

\section{Contractional structures}

Our data seem to indicate the existence of two different families of folds: the first with axes NW-SE and the second with axes NE-SW (Fig. 5 , Table 2).

$N W-S E$ fold axes. NE-SW shortening has been observed in different localities of the TPB in sediments as young as Tortonian (Figs 5 \& 6)

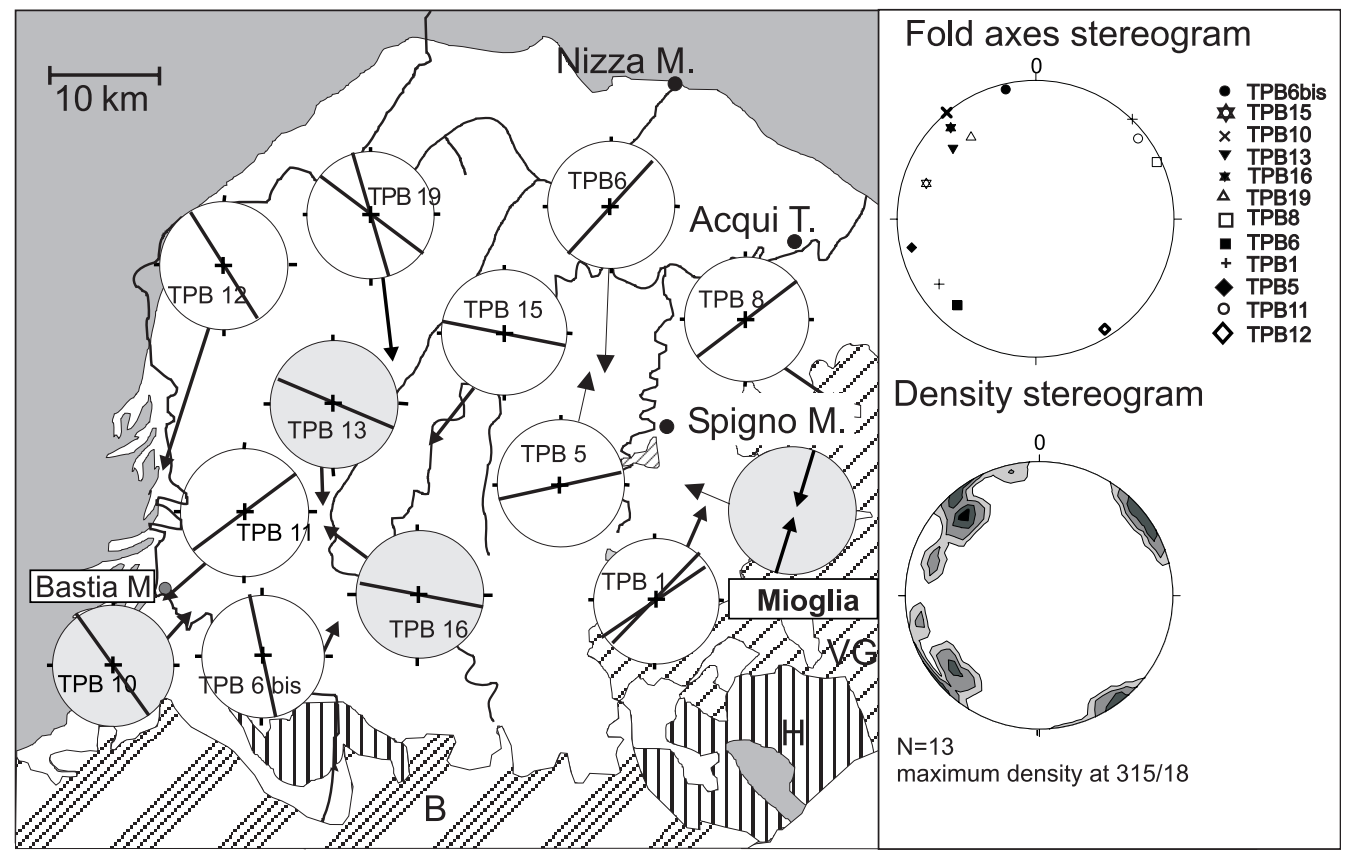

Fig. 5. Location of folds and relative axes detected in the TPB from this study (and of the Mioglia fold, from Bernini \& Zezza 1990). Grey plots indicate synsedimentary structures. A density diagram is also provided. VG, Voltri Group; H, Hercynian Crystalline Massifs; B, Briançonnais domain. 
Table 2. Depositional time, formations, and coordinates (UTM, zone 32T) of sites used for structural studies mentioned in the text.

\begin{tabular}{|c|c|c|c|}
\hline Sites & Formations & Depositional time & $\begin{array}{l}\text { UTM coordinates } \\
\text { zone } 32 \mathrm{~T}\end{array}$ \\
\hline TPB1bis & Molare Fm & Rupelian & $448390-493148$ \\
\hline ТРB7 & Molare Fm & Rupelian & $461000-493412$ \\
\hline TPB8 & Molare Fm & Rupelian & $459700-493380$ \\
\hline TPB4 & $\begin{array}{c}\text { Rocchetta Fm (muddy matrix, Gelati \& } \\
\text { Gnaccolini 1998) }\end{array}$ & Rupelian-Aquitanian & $446720-493590$ \\
\hline TPB2 & Rocchetta Fm (Noceto system) & Rupelian-Aquitanian & $444110-423250$ \\
\hline TPB6 & $\begin{array}{l}\text { Rocchetta Fm (muddy matrix, Gelati \& } \\
\text { Gnaccolini 1998) }\end{array}$ & Rupelian-Aquitanian & $445410-493563$ \\
\hline TPB6bis & Paroldo Marls & Rupelian-Aquitanian & $425530-491956$ \\
\hline ТРB9 & $\begin{array}{l}\text { Monesiglio Fm (system N3, Gelati \& } \\
\text { Gnaccolini 1996) }\end{array}$ & Chattian & $415780-491670$ \\
\hline TPB3 & $\begin{array}{l}\text { Monesiglio Fm (glauconite-rich hybrid arenites, } \\
\text { Gelati \& Gnaccolini 1998) }\end{array}$ & Aquitanian & $446300-493691$ \\
\hline Mioglia & Rocchetta Fm (see Bernini \& Zecca, 1990) & Rupelian-Burdigalian & $453000-492480$ \\
\hline TPB1 & $\begin{array}{c}\text { Rocchetta Fm (Mioglia system, Cazzola \& } \\
\text { Sgavetti 1983) }\end{array}$ & Chattian-Burdigalian & $452502-492717$ \\
\hline TPB5 & $\begin{array}{c}\text { Rocchetta Fm (Piantivello body, Gelati \& } \\
\text { Gnaccolini 1998) }\end{array}$ & Burdigalian & $443360-493583$ \\
\hline TPB15 & Cortemilia Fm & Aquitanian-Langhian & $431500-493228$ \\
\hline TPB11 & - & Aquitanian-Serravallian? & $412200-492207$ \\
\hline ТPB10 & Murazzano Fm? & Langhian & $414400-492041$ \\
\hline TPB13 & Cassinasco Fm & Langhian-Serravallian? & $424110-492738$ \\
\hline TPB16 & Cassinasco Fm & Langhian-Serravallian & $424110-492645$ \\
\hline ТРВ17 & Lequio Fm & Serravallian-Tortonian & $493047-418980$ \\
\hline ТPB19 & Lequio Fm & Serravallian-Tortonian & $426920-493800$ \\
\hline TPB 12 & Lequio Fm? & Tortonian? & $413400-492901$ \\
\hline
\end{tabular}

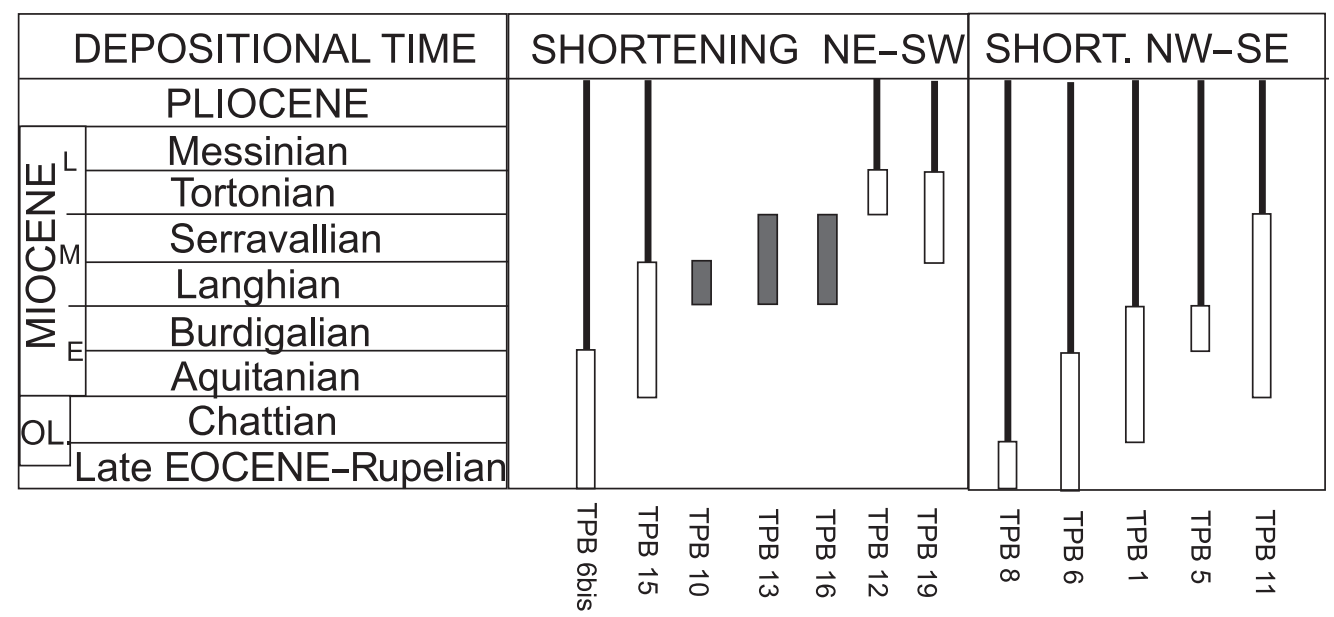

Fig. 6. Age constraints of shortening. White bars, age of sediments in which shortening has been found to correspond with the maximum deformation age. The possible age of shortening is younger than the white bars, and is indicated by thick black lines. Grey bars, synsedimentary structures. 
represented mainly by open asymmetrical anticlines and a few closed folds from tens to hundreds of metres in dimensions.

A number of these structures have a synsedimentary character and developed during Langhian-Serravallian times (TPB 10, 13, 16; Figs 7-9). Possibly the most spectacular NW-SE synsedimentary-trending fold is the Ciglie anticline (TPB 10, Fig. 7) where the growing structure is unconformably onlapped by a subhorizontal turbidite sequence which has been dated as Middle Langhian (D'Atri, pers. comm.). Other structures with similar shortening geometries developed in soft sediments are presently well exposed along road cuttings near the Bossola Pass (TPB 13, TPB 16; Figs 8 \& 9). Site TPB 13 corresponds with an asymmetrical closed syncline overturned toward the NE. This fold developed while the sediments were still soft and therefore it is representative of synsedimentary deformation (Fig. 10). A low-angle normal fault in the hinge of the anticline is associated with fold development and is sealed by an undeformed stratum (on the top of the SW flank, Fig. 8). Site TPB 13 is the only example we have of an overturned structure representing strong deform- ation. Because of the lack of subsurface data, we cannot say whether this deformation is associated with a major deep structure. Site TPB16 (Fig. 9) corresponds with a box fold with axis $317 / 11$ and related reverse faults 220/18, 247/40 with movements towards the NE. This developed while the sediments were still soft and therefore it is representative of a synsedimentary deformation fold as site TPB 13 .

TPB 12 and TPB 19 indicate that NE-SW shortening also affected Tortonian sediments. Therefore on the basis of the observed structures indicated above we conclude that NE-SW shortening was active during Langhian-Tortonian times although the lack of information on the Messinian does not allow a better upper age limit to be given.

$N E-S W$ fold axes. NW-SE shortening has been observed in five different localities of the TPB (Fig. 5). A good example of a NE-SW fold axis is TPB 11 (near Bastia Mondovi) which has been detected in Lower-Middle Miocene sediments. The TPB 11 is a $200 \mathrm{~m}$ open asymmetrical anticline with subhorizontal strata in the SE and with dips up to $30^{\circ}$ on the NW flank.
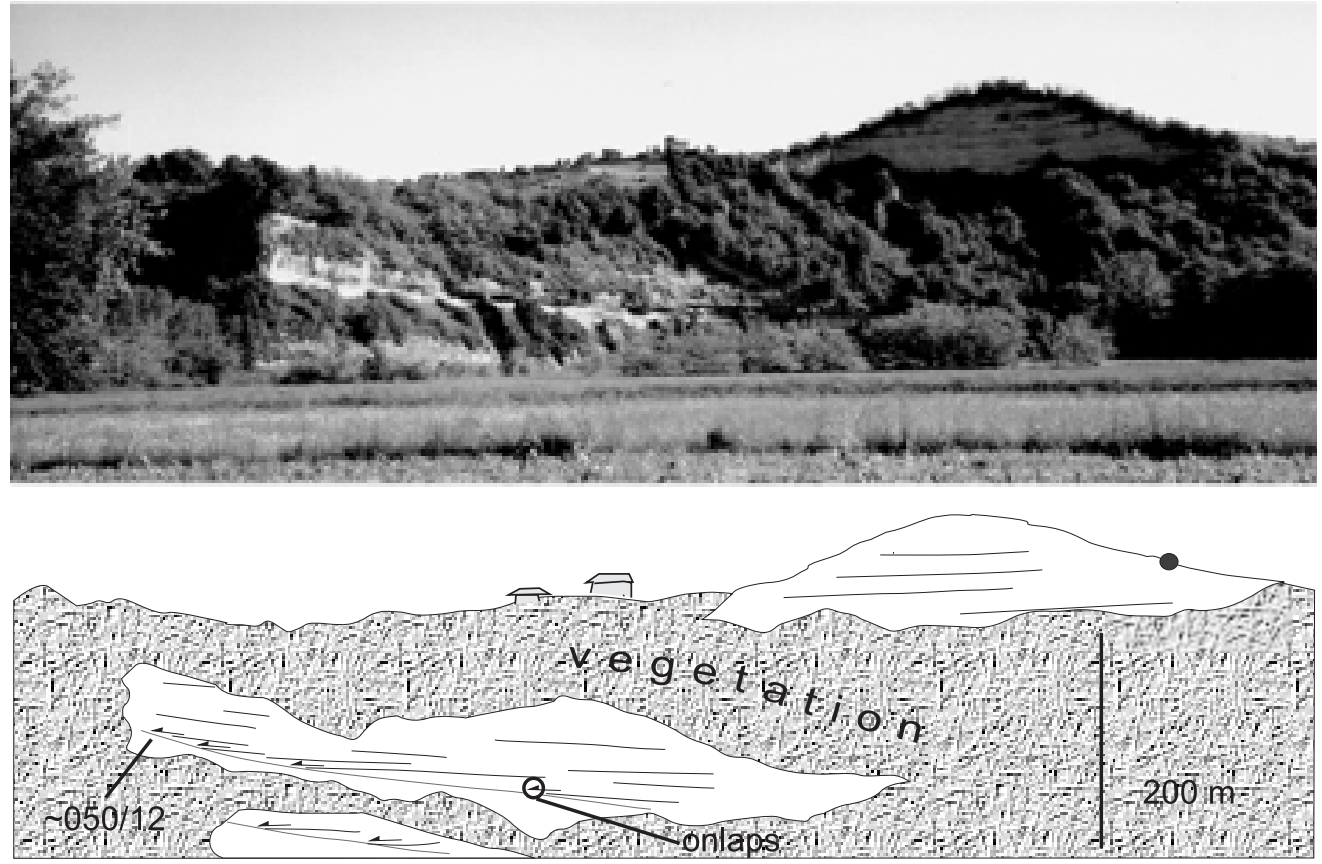

Fig. 7. Example of NE-SW-directed synsedimentary shortening: site TPB 10, Ciglie growing anticline. The sample indicated with the black dot has been dated as Middle Langhian (d'Atri, pers. comm.). 


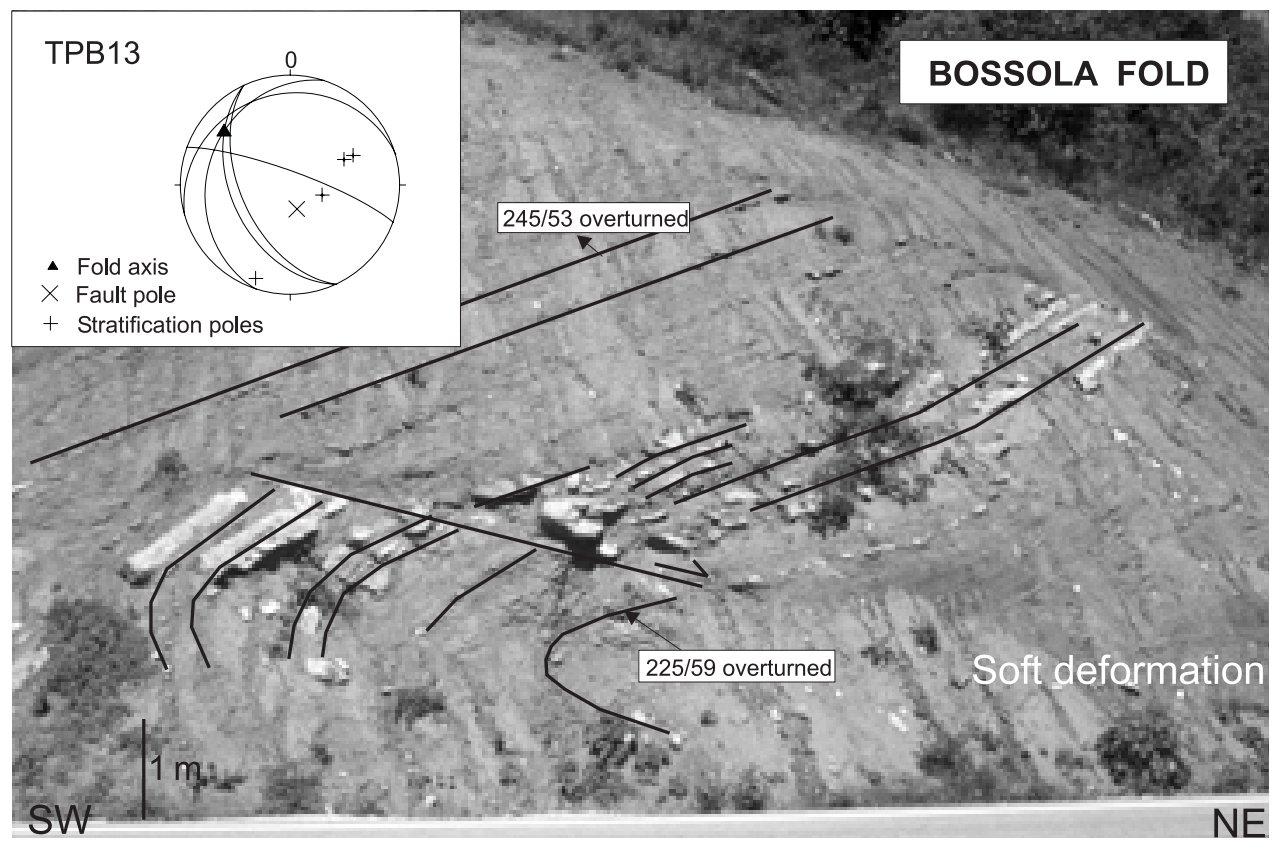

Fig. 8. Example of NE-SW directed synsedimentary shortening: site TPB 13, Bossola fold.

The NE-SW-trending folds never display a synsedimentary character (Fig. 6). For this reason we interpret NW-SE shortening to be younger than NE-SW shortening, namely postTortonian.

\section{Extensional structures}

Palaeostress analysis on small-scale structures suggests a fairly homogeneous north-south tension over the entire basin (Figs 10-12). All of these extensional structures have been detected in Rupelian to Tortonian sediments (Fig. 12). Synsedimentary extension has been detected only in one site (TPB 17) in the Lequio Formation (Serravallian-Tortonian), represented by a set of normal faults with a few centimetres offset and strata thickening toward the fault plane. Our data suggest a north-south tension active at least during Serravallian-Tortonian times.

\section{Magnetic anisotropy \\ Method and input data}

The anisotropy of magnetic susceptibility (AMS) of ferromagnetic minerals is widely used to provide information on the tectonic history of weakly deformed sediments (Scheepers \&
Langereis 1994; Duermeijer et al. 1998), such as those present in the TPB. The AMS is represented by a second-order tensor, which can be visualized using a three-axis ellipsoid ( $K_{\max }$, $K_{\text {int }}$ and $\left.K_{\min }\right)$. The total degree of anisotropy is defined by $P=K_{\max } / K_{\text {int }}$; the magnetic foliation is defined by $F=K_{\text {int }} / K_{\min }$ and the magnetic lineation, which is the degree of anisotropy in the magnetic foliation plane, is defined by $L=K_{\max } / K_{\text {int }}$ (Tarling \& Hrouda 1993). The orientation of the AMS ellipsoid is in most cases congruent with the strain ellipsoid. In finegrained rocks, such as the studied sediments, the preferred orientation of phyllosilicates depends on the strain caused by compaction and tectonic processes (Clark 1970; Moore \& Geigle 1974; Oertel 1983; Peterson et al. 1995), although depositional currents can also account for lineation. Several studies have shown the relationships between magnetic fabric and strain in compressional regimes (Kissel et al. 1986; Lee et al. 1990; Scheepers \& Langereis 1994). In weakly deformed sediments, the orientation of $K_{\min }$ is perpendicular to the bedding plane, while the orientation of $K_{\max }$ is generally perpendicular to the direction of major shortening (Lee et al. 1990; Tarling \& Hrouda 1993). An increase in strain causes the ellipsoid to have a more prolate structure (Lee et al. 1990; Tarling \& 


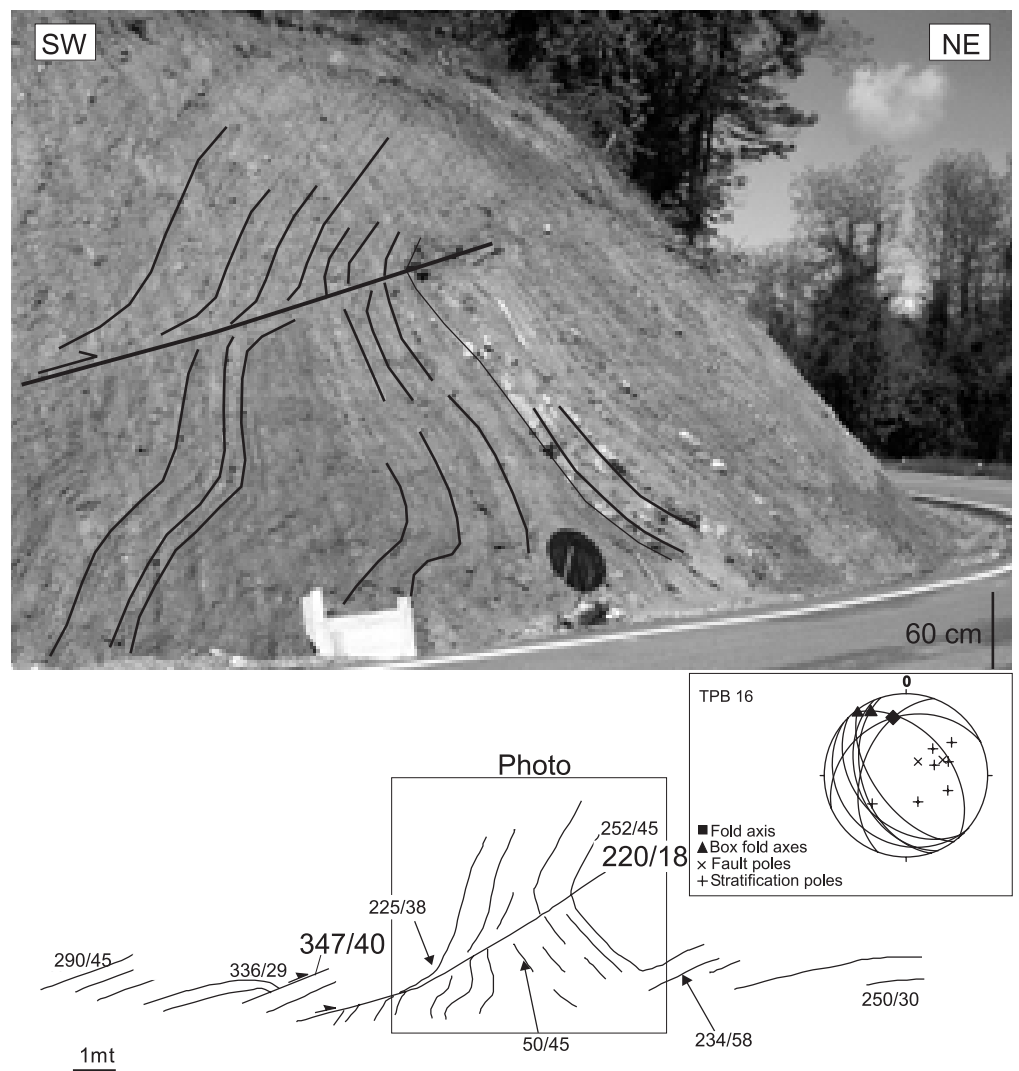

Fig. 9. Example of NE-SW-directed synsedimentary shortening: site TPB 16, fold box (100 m south of the Bossola fold); drag folds associated with the fault constrain the displacement direction.

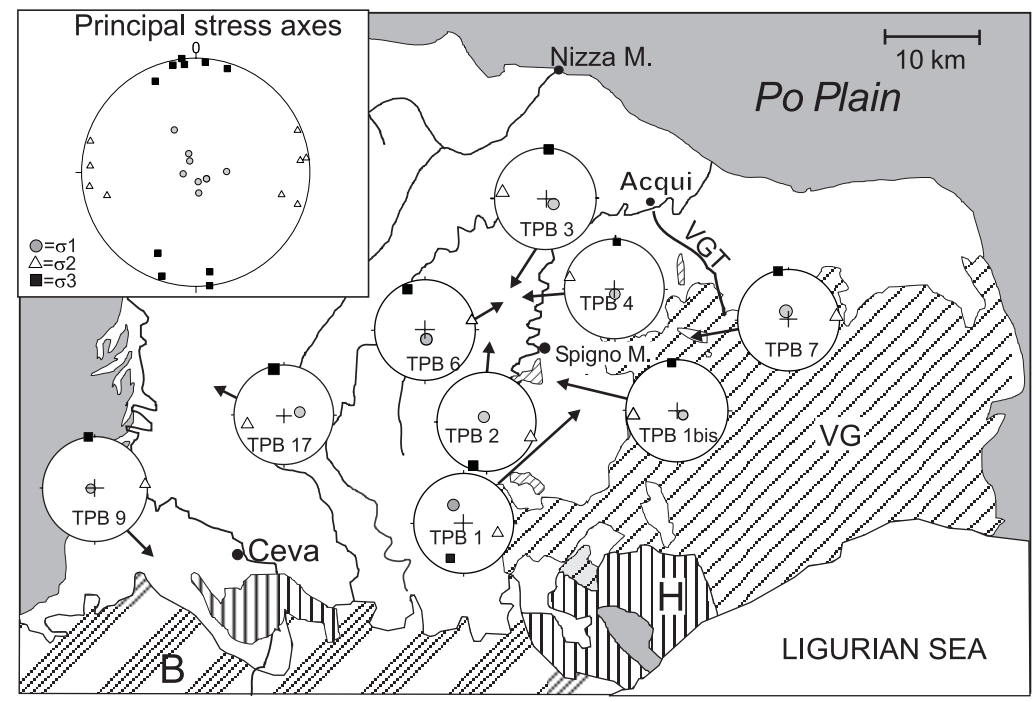

Fig. 10. Sites and results of palaeostress analysis. Summary of results in the upper left square. VG, Voltri Group; H, Hercynian Crystalline Massifs; B, Briançonnais domain. VGT, Val Gorrini Thrust. 

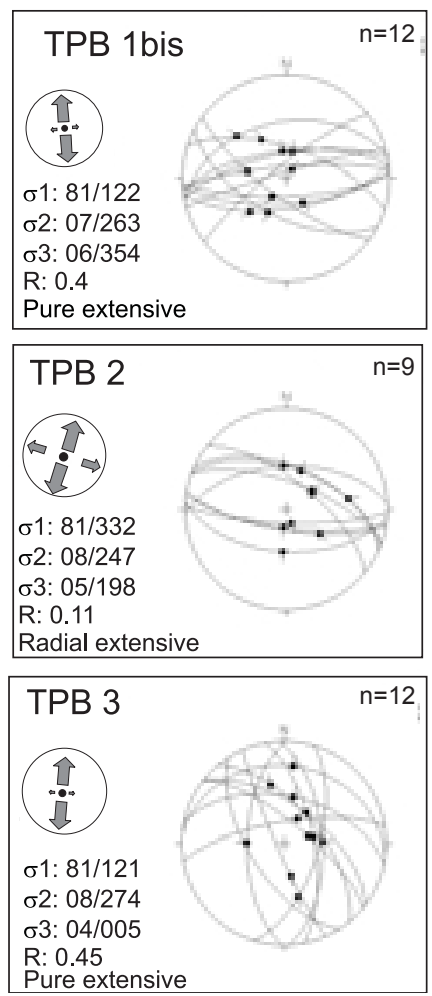
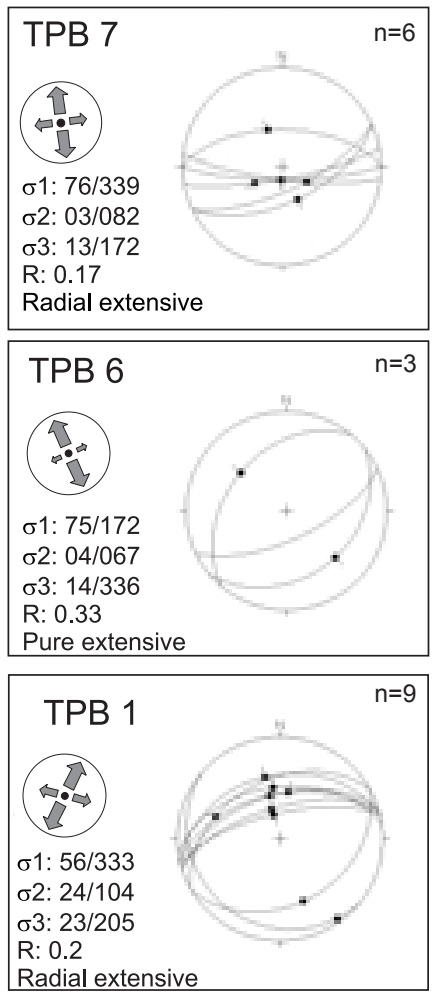
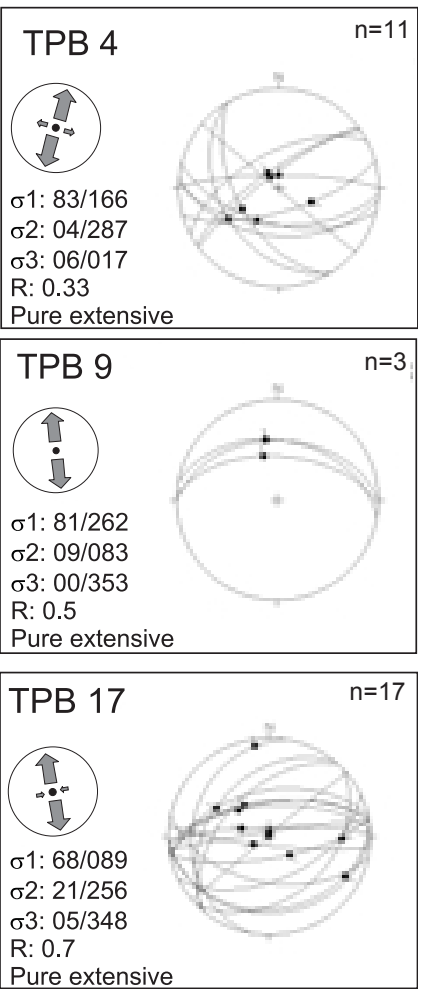

Fig. 11. Stereoplots of normal faults measured in the TPB; site locations are given in Figure 10. R, stress ellipsoid shape ratio.

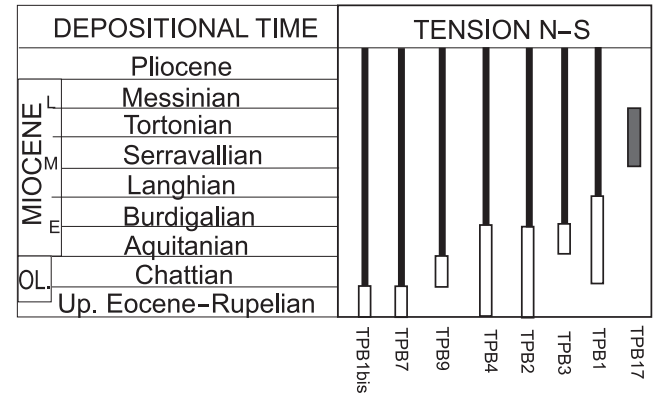

Fig. 12. Age determination for north-south tension. White bars, age of sediments in which tension has been found and therefore maximum deformation age. The possible age of tension is younger than the white bars and indicated by thick black lines. Grey bars: synsedimentary structures.

Hrouda 1993). Therefore the magnetic lineation $(L)$, in weakly deformed sediment strongly depends on the stress field (Kissel et al. 1986) allowing comparison with structural data. A high value of $L$ is most likely to be related to synsedimentary deformation, since the fabric of sediments is more easily affected by strain when they are relatively soft and unconsolidated (Borradaile 1988; Mattei et al. 1997).

Samples have been collected within shale/silt layers belonging to the entire stratigraphic sequence and covering the entire basin (Fig. 13; Table 3). AMS measurements were carried out using a high-sensitivity low-field susceptibility bridge (KLY-3) at Fort Hoofddijk, University of Utrecht. The mean ellipsoids have been calculated according to Jelinek (1978). Furthermore in this work only values of $K_{\max }$ with $\mathrm{d} D$ (errors) $<25$ have been considered as being representative of shortening directions. The locations of all sites are shown in Fig. 13, but with only the most representative results for the AMS axes while the complete AMS data are presented in Fig. 14.

\section{Results}

AMS data show the existence of two directions of shortening, respectively NE-SW and NW-SE, supporting the directions of deformation 


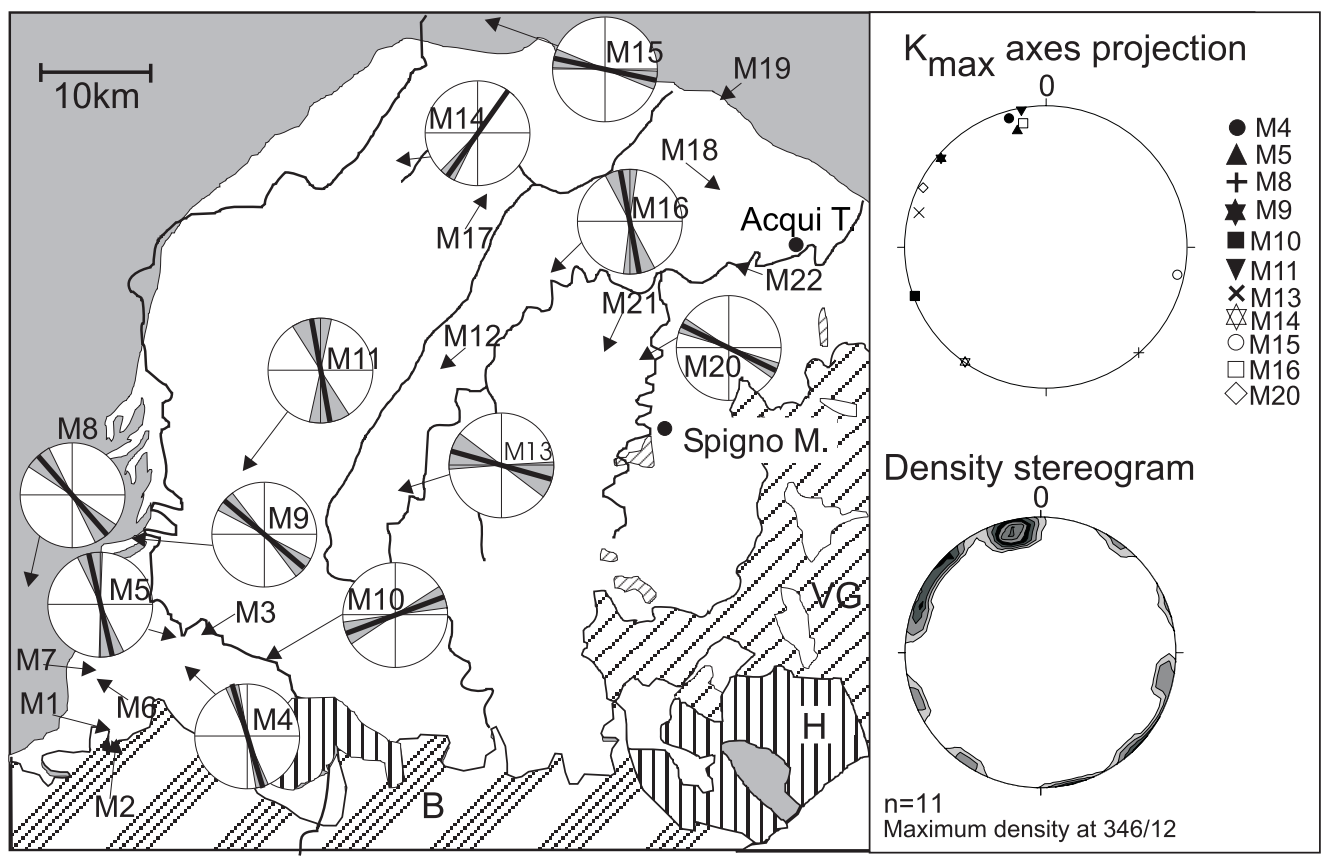

Fig. 13. Location of AMS and NRM analysis. Stereoplots indicate the results of AMS measurements; shaded segment represents error on mean $K_{\max }$ axes $(\mathrm{d} A z)$ with solid line as mean lineation $(L)$ direction per section. Only sites with $\mathrm{d} D<25$ have been plotted. Density diagram allows a comparison with the structural data in Figure 5. VG, Voltri Group; H, Hercynian Crystalline Massifs; B, Briançonnais domain.

detected with structural analysis (Figs 13 \& 14). This confirms the statement that the AMS ellipsoid can be associated with regional deformations. This assumption is further supported by the trend of magnetic lineation, which differs from the palaeocurrent directions in the same area (Gelati et al. 1993).

In some cases, an age of deformation can be proposed. This is the case of sediments with high $L$. Very high values of $L$ correspond in general with NW-SE AMS axes, which can be related to NE-SW shortening (Table 3; Fig. 13). In particular they occur in Lower OligoceneAquitanian sediments (site M20), in Upper Oligocene-Lower Miocene sediments (site M4), and in Middle Langhian sediments (site M5) (Table 3; Fig. 13). Furthermore, site M5 has been measured on the Ciglie Anticline (Fig. 7) supporting the relationship between shortening (in this case synsedimentary) and AMS data (especially high values of $L$ ).

\section{NRM analysis for rotations}

Palaeomagnetic results and palaeoreconstruction models from areas surrounding the TPB suggested that significant counterclockwise rotations took place during Oligo-Miocene times (Burrus 1984; Boccaletti et al. 1990; Vanossi et al. 1994; Vigliotti \& Langenheim 1995; Bormioli \& Lanza 1995; Muttoni et al. 2000). Since no palaeomagnetic data were available for the TPB itself, we have performed a demagnetization analysis on sediments from the entire basin in order to investigate the tectonic rotation history. NRM analysis was also performed on Pliocene sediments that seal the geometrical relationships between the TPB basin and the surrounding areas (e.g. the Po Plain), providing information on this particular timespan.

\section{Method and input data}

The study of the natural remanent magnetization (NRM) in rock samples was carried out in order to derive the characteristic remanent magnetization (ChRM), which can be used to estimate tectonic rotations. Samples were collected from the entire basin (Fig. 13) and covering the whole stratigraphic interval (Table 4). The ChRM component was obtained by means of pro- 

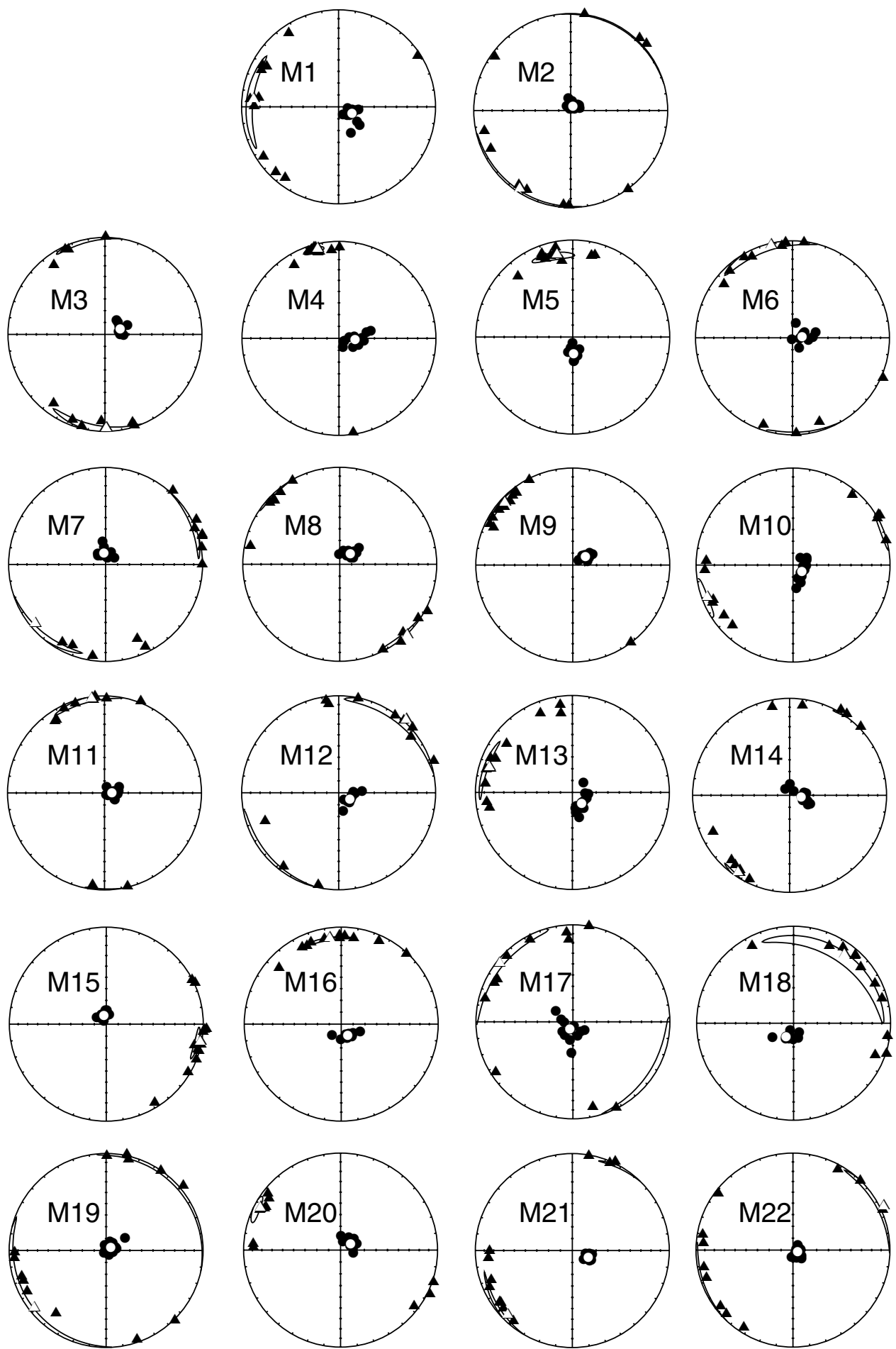

Fig. 14. Equal area projection of $K_{\max }$ (triangles) and $K_{\min }$ (circles) of the ellipsoid of the AMS for the individual samples, with the calculation of the mean ellipsoid according to Jelinek (1978). 


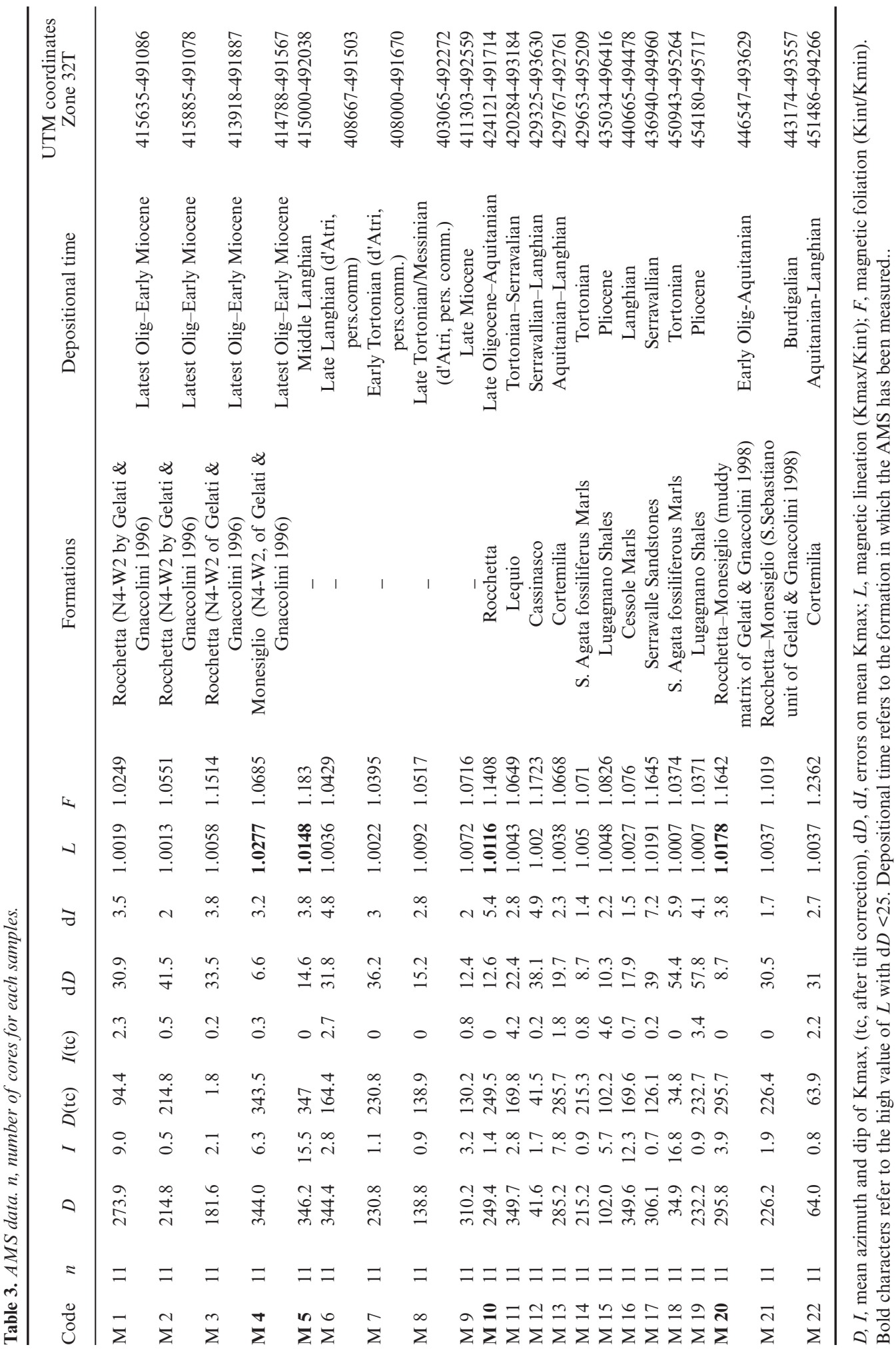


Table 4. Results from NRM analysis from the different sites of the TPB (see Fig. 13 for location).

\begin{tabular}{|c|c|c|c|c|c|c|c|c|}
\hline Site & Pol. & $\mathrm{N}$ & Dec & Inc & $\mathrm{k}$ & a95 & rot. & Dep. Age \\
\hline M01 & $\mathrm{R}$ & 9 & 167 & -46 & 147 & 4 & -13 & Latest Oligocene-Early Miocene \\
\hline M01* & $\mathrm{R}$ & 9 & 167 & -47 & 199 & 4 & -13 & Latest Oligocene-Early Miocene \\
\hline M03 & $\mathrm{R}$ & 11 & 157 & -52 & 76 & 5 & -23 & Latest Oligocene-Early Miocene \\
\hline M03* & $\mathrm{R}$ & 11 & 141 & -55 & 67 & 6 & -39 & Latest Oligocene-Early Miocene \\
\hline M05 & $\mathrm{R}$ & 8 & 135 & -45 & 45 & 8 & -45 & Middle Langhian \\
\hline $\mathrm{M} 05^{*}$ & $\mathrm{R}$ & 9 & 150 & -51 & 84 & 6 & -30 & Middle Langhian \\
\hline M06 & $\mathrm{N}$ & 4 & 340 & 53 & 167 & 7 & -20 & Late Langhian \\
\hline M07 & $\mathrm{R}$ & 10 & 190 & -36 & 3 & 35 & 10 & Early Tortonian \\
\hline $\mathrm{M} 07 *$ & $\mathrm{R}$ & - & - & - & - & - & - & Early Tortonian \\
\hline M08 & $\mathrm{N}$ & 11 & 17 & 69 & 141 & 4 & 17 & Late Tortonian/Messinian? \\
\hline M09 & $\mathrm{R}$ & 6 & 193 & -48 & 23 & 14 & 13 & Late Miocene \\
\hline M10 & $\mathrm{N}$ & 8 & 345 & 45 & 31 & 10 & -15 & Late Oligocene-Aquitanian \\
\hline M13 & $\mathrm{N}$ & 11 & 355 & 52 & 80 & 5 & -5 & Aquitanian-Langhian \\
\hline M14 & $\mathrm{N}$ & 11 & 3 & 62 & 15 & 12 & 3 & Tortonian \\
\hline M15 & $\mathrm{N}$ & 11 & 353 & 49 & 143 & 4 & -7 & Pliocene \\
\hline M19 & $\mathrm{N}$ & 11 & 359 & 41 & 30 & 9 & -1 & Pliocene \\
\hline M20 & $\mathrm{N}$ & 11 & 299 & 27 & 10 & 15 & -61 & Early Oligocene-Aquitanian \\
\hline
\end{tabular}

* AF demagnetization. N, number of specimens; Dec, Inc, site mean ChRM declination and inclination; $\mathrm{k}$, Fisher's precision parameter; a95, 95\% cone of confidence; rot, angle of rotations (counterclockwise). Grey areas corresponds with the age of sediments affected by counterclockwise rotation $\left(>10^{\circ}\right)$.
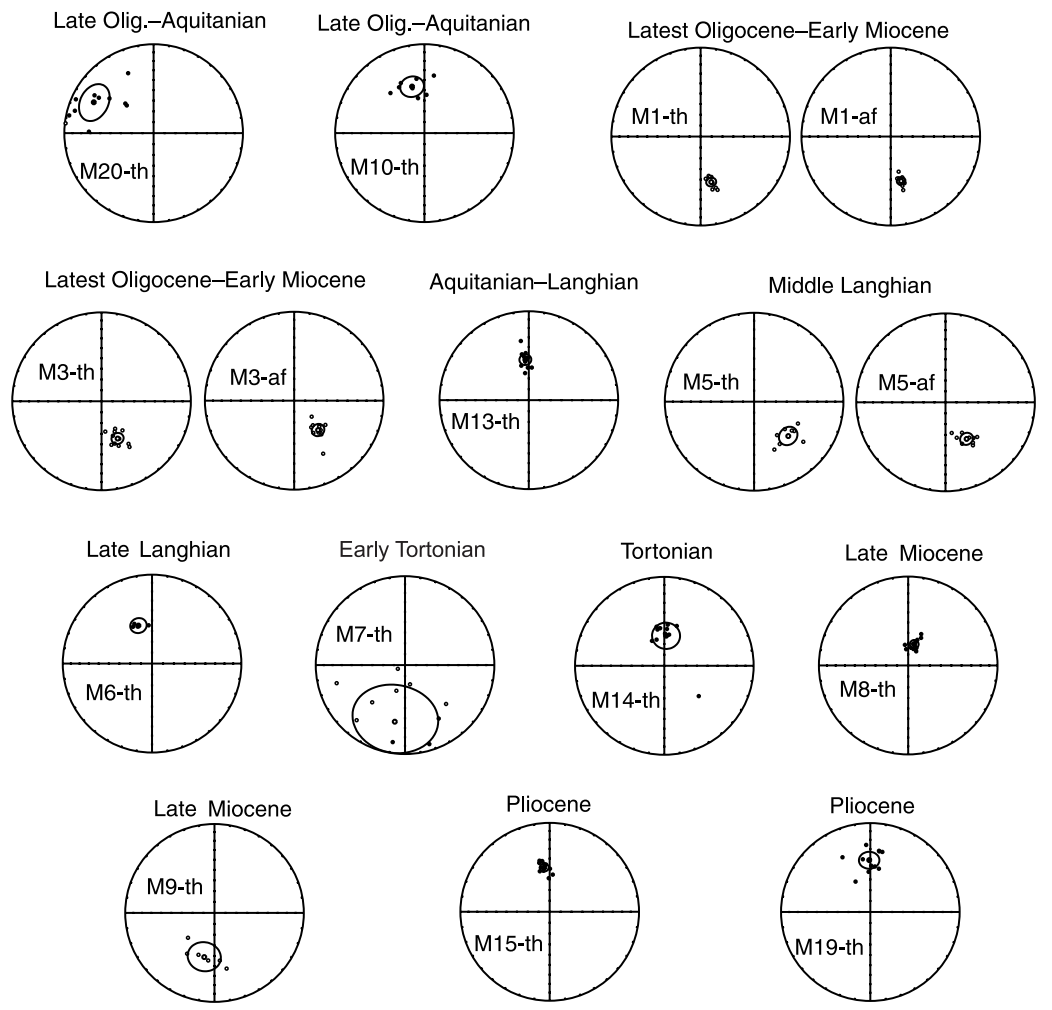

Fig. 15. Equal area projection of ChRM components of samples from the TPB. Dots represent the individual sample directions; full (open) dots represent downward (upward) projections. The circles give a95 (Fisher's 1953) for the different site means. 
gressive stepwise thermal demagnetization (TH) using small temperature increments $\left(30-50^{\circ} \mathrm{C}\right)$ (Fig. 15) and, for some samples, by alternating field demagnetization (AF) (Fig. 16). This latter method involves increasing at each step the alternating field strength instead of the temperature. Each mineral has its characteristic unblocking field in the same way that it has a typical unblocking temperature. In the perfect case the same rotation should be obtained by both techniques. The NRM was measured for all the samples with a $2 \mathrm{G}$ Enterprise DC SQUID cryogenic magnetometer. Demagnetization diagrams were used for the interpretation of representative samples (Fig. 16). The ChRMcomponents were determined by calculating best-fit lines through data-points belonging to specific temperature intervals. Demagnetization vectors were finally combined using Fisher statistics (Fisher, 1953) to calculate mean directions per site. Palaeomagnetic analyses were performed on 22 sites, each consisting of 11 samples, but only 13 sites gave reliable results (Figs 15 \& 17; Table 4). In general all samples show an NRM which is largely removed at temperatures of $360-450^{\circ} \mathrm{C}$ or at fields of $80 \mathrm{mT}$. Demagnetization at higher temperatures commonly resulted in the generation of a randomly oriented viscous component.

\section{Results}

Thermal demagnetization analyses show that the Oligocene-Early Miocene sites of the TPB have been affected by rotation (Figs 15-17). Only sites with rotations $>10^{\circ}$ are here considered as representative.

Most sites, especially in the SW part, show a counterclockwise rotation of an average of few tens of degrees around $20^{\circ}$ (sites: M1, M3, M5, M6, M10 and M20; Fig. 17; Table 4). The counterclockwise rotation from sites M1, M3, M5 is also confirmed by the AF demagnetization data (Figs 16 \& 17; Table 4). Two sites (M20 and M5) show an anomalous high rotation between 45 and $61^{\circ}$, possibly due to local processes. Only two sites in the southwestern area (M8 and M9) show a representative $\left(>10^{\circ}\right)$ clockwise rotation.

A tentative time constraint is here made by looking at the depositional time of sediments involved in counterclockwise rotations. In general, rotations greater than $10^{\circ}$ are restricted to sediments as old as Late Langhian, while Tortonian-Pliocene sediments show no rotations (Fig. 15; Table 4). Therefore, a Middle Miocene age (Serravallian) is suggested for the tectonic phase responsible for the counterclockwise rotation of the TPB.

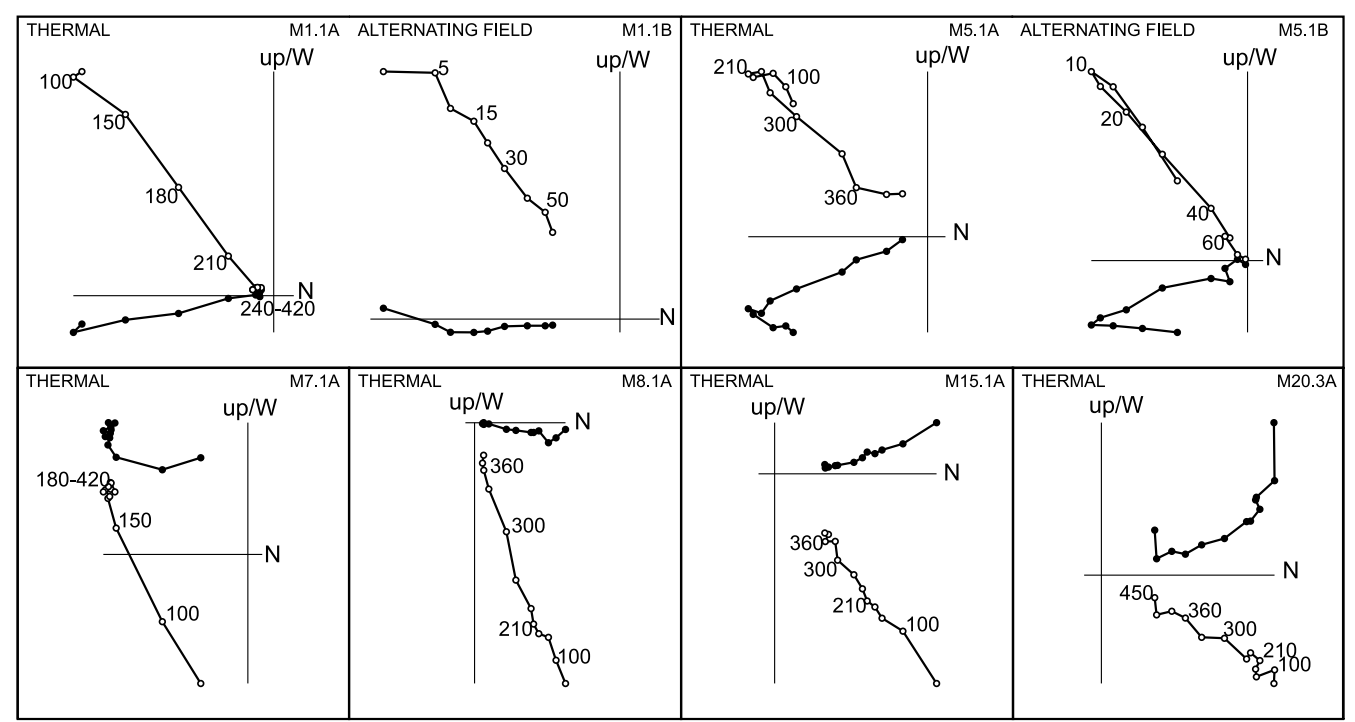

Fig. 16. Stepwise thermal demagnetisation diagrams of the individual specimens from the most representative site of the TPB, and comparison with the alternating field demagnetisation method. Dots are projections on the horizontal plane and circles are projected on the vertical north-south or east-west plane. Numbers denote demagnetisation steps in ${ }^{\circ} \mathrm{C}$ and $\mathrm{mT}$, respectively. 


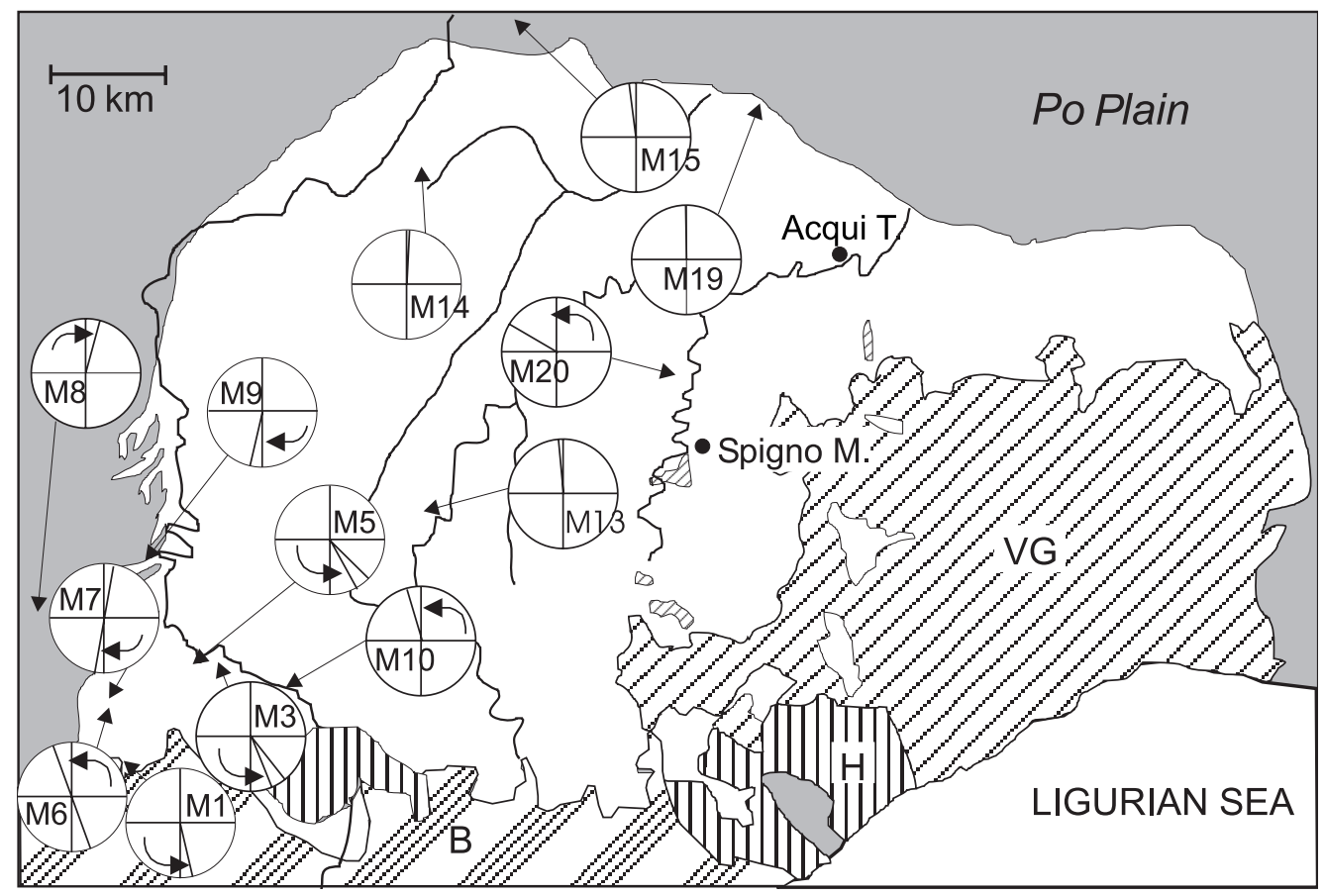

Fig. 17. Diagram showing rotations (from Fig. 15) related to different sites. Only angles $>10^{\circ}$ are considered as representative. VG, Voltri Group; H, Hercynian Crystalline Massifs; B, Briançonnais domain.

\section{The evolution of the TPB}

Subsidence affecting the westernmost segment of the Western Alpine orogen, that is, the Ligurian Alps, allowed the deposition of transitional sediments on top of the orogen, progressively younging from the NE (Late Eocene-Early Oligocene) to SW (Late Oligocene), thereby initiating the evolution of the TPB. Subsidence was fairly constant from the Oligocene until the Middle Miocene, with the exception of an Oligocene episode of subsidence acceleration in the SW part of the basin. The stress/strain regime during Oligocene to Early Miocene times is poorly resolved. Some north-south tensional stresses have been detected in several parts of the basin, especially in its SE portion. They are compatible with relatively small ENE-WSW- to WNW-ESE-trending normal faults mapped in the SE parts of the basin (Bernini \& Zecca 1990; Mutti et al. 1995; Gelati \& Gnaccolini 1998). The overall extension accommodated by these faults is of the order of several hundred metres (c.1700 $\mathrm{m}$ by measurement of the horizontal displacements) and, therefore, they are indicative of stress rather than substantial strain. During the same time interval, Late Oligocene to Early
Miocene NE-SW compression caused the formation of few contractional structures such as the NNW-SSE-trending Mioglia fold in the south and open anticlines in the eastern parts of the basin (Bernini \& Zecca 1990; Gelati \& Gnaccolini 1998). This phase of shortening fits in well with our AMS data. Timing and thus the genetic relations between north-south tension and NE-SW shortening remain unclear.

From the Early to Middle Miocene, strong subsidence affected large parts of the TPB. Little is known from the southern part of the basin where Miocene sediments are lacking. Similarly to what was discussed for the previous time-span, the observed structures are quite widespread but systematically associated with small displacements. No significant extensional features have been detected. The NE-SW-directed compression and limited shortening remained active through Serravallian-Tortonian times, producing synsedimentary structures such as those observed at sites TPB 10, TPB 13 and TPB 16 (Figs 8 \& 9).

Serravallian and older sediments also experienced NW-SE-directed compression associated with the formation of small- and some larger- 
scale folds. The age of this deformation stage is poorly constrained, but because of the consistent lack of synsedimentary activity we interpret the NW-SE directed compression to be younger than the NE-SW-directed one and therefore post-Tortonian. Despite these uncertainties, it is clear that the entire Miocene TPB evolution took place under a NE-SW- to NW-SE-trending prevailing compressional regime.

\section{The TPB and its regional context}

Our new palaeomagnetic data show that TPB sediments experienced a fairly small $\left(c .20^{\circ}\right)$ counterclockwise rotation in Middle Miocene times, following which the TPB has basically acquired its present-day position. The stress/ strain geometries that we have obtained are thus not substantially different from their original position.

The TPB sediments transgress and only partly seal the pre-Oligocene structures developed in the Ligurian Alps contractional domain (Vanossi et al. 1984), since evidence of thrusts in the Ligurian Alps during Oligo-Miocene times over the TPB sediments (Hoogerduijn Strating et al. 1991; Piana et al. 1997) suggest that the compressional structures in the belts were still active during this time-span.

The Oligocene to Early Miocene basin was lying between the subsiding Po Plain 'foredeep' in the north (Dela Pierre et al. 1995) and the extensional Liguro-Provençal Basin in the SW. During this time-span the TPB was undergoing general NE-SW shortening.

During Late Oligocene-Early Miocene times, the eastern margin of the TPB experienced NE-SW shortening responsible for the NEverging Alto Monferrato thrusts (e.g. VGT in Fig. 1; Piana et al. 1997) and the overthrusting of the Ligurian units on to the Tuscan units along the Villalvernia-Varzi-Line (VVL in Fig. 1a; Miletto \& Polino 1992). The same time-span corresponds with the activity period of the transpressive Rio Freddo Deformation Zone (RFDZ in Fig. 1a), which has been interpreted as the superficial expression of a palaeo-Apenninic thrust (Piana 2000). This phase of transpression and shortening falls within the palaeo-Apenninic phase of deformation, which in the Alpine domain coincides with the Insubric-Helvetic phase, caused mainly by the NW-SE AfricaEurope convergence (Laubscher 1991). The Po Plain was also undergoing subsidence, allowing the deposition of a thick clastic succession probably connected to the TPB.

To the SW of the TPB, a NE-SW continental rift developed in Oligocene times between
France/Spain and the Corsica-Sardinia block, leading to Late Oligocene crustal separation and generation of oceanic crust (e.g. Burrus 1984; Jolivet et al. 1999). Spreading and drifting ended in the Early Miocene with the shift of the extension site to the east of the Corsica-Sardinia block.

Tectonic and dynamic relationships between the TPB on one side and the Po Plain and Liguro-Provençal Basin on the other are still unclear. Small normal faults found in the south of the basin possibly could be associated with the Liguro-Provençal rifting. However, the clear predominance of compressional stresses during the Oligocene to Early Miocene TPB evolution suggests that the basin was essentially a part of the western Po Plain compressional system.

During the Middle-Late Miocene, the western Po Plain was undergoing roughly $c$.N-S-directed shortening, with the development of the southverging Milano belt (Jura-Lombardic deformation phase; Laubscher 1992; Schumacher \& Laubscher 1996) and strong subsidence. Between the Langhian and the Serravallian the NW Apennine were undergoing roughly NE-SW shortening, responsible for the emplacement of the Ligurian units on to the Modino-Cervarola and Umbro-Marchean units (Pedeapennine Thrust Front, Boccaletti et al. 1985). On the western margin of the TPB in Middle Miocene to Pliocene times, active tectonic shortening was responsible (Saluzzo Basin; Fig. 1) for the formation of the Saluzzo fold (Pieri \& Groppi 1981). During the same time-span the eastern margin of the TPB was still affected by shortening ( $c . \mathrm{NW}-\mathrm{SE})$ responsible for the shifting towards the north of the Alto Monferrato thrust fronts (Falletti et al. 1995). By this time, deformation in the Ligurian Alps had ceased.

From the Pliocene to Quaternary, the NeoApenninic deformation phase is responsible for tectonic shortening leading to the formation of the Plio-Quaternary Padan thrust front (Fig. 1d) and for the translation towards the north of the Torino Hill (e.g. Piana \& Polino 1995) and probably for the present-day TPB elevation.

\section{Conclusion}

The TPB, despite being located on top of an orogenic belt, subsided in Oligocene to Miocene times, allowing the deposition of up to $4 \mathrm{~km}$ of clastic sediments. Normal faults detected so far in the TPB are not enough to explain the total amount of subsidence $(4-5 \mathrm{~km})$ present in the TPB basin from Oligocene until Late Miocene times. Furthermore, no regional normal faults have been detected so far in the area. Small-scale 
normal faults detected in Oligocene-Miocene sediments could be related to the extensional phase responsible for the opening of the LiguroProvençal Basin.

The Miocene is characterized by general strong subsidence and NE-SW to NW-SE shortening. In particular, the Middle Miocene constitutes an important period in the evolution of the TPB, with an acceleration of subsidence under a prevalent NE-SW tectonic shortening. General shortening was active in the same timespan on the western margin of the Po Plain and in the Northern Apennine. In particular, NE-SW to NW-SE directions of shortening detected in TPB sediments fit well with the post-Eocene pattern of NE-SW arc-normal transport direction of the Western Alpine arc proposed by Platt et al. (1989), and with the NE-SW and NW-SE directions of shortening detected in the Ligurian Alps (close to the boundary with the Northern Apennine) by Hoogerduijn Strating et al. (1991). The latter authors have suggested a possible superposition of two displacement directions of different ages, and in particular proposed a Late Miocene age for the NW-SE shortening related to the development of the Monferrato culmination (Hoogerduijn Strating et al. 1991), supporting our data. At this stage there is uncertainty exists regarding the mechanism responsible for the accommodation space in the TPB under prevalent tectonic shortening.

New preliminary NRM data show general $20^{\circ}$ counterclockwise rotations of approximately Serravallian age. These new results show that the TPB was not affected by rotations during Tortonian to Quaternary times, despite ongoing shortening in the Apennine domain (e.g. Clari et al. 1995; Schumacher \& Laubscher 1996). Our data seem to be fairly consistent with rotations detected in the eastern and northern parts of the TPB (Thio 1988; Bormioli \& Lanza 1995) and in the Northern Apennine for the Oligocene-Miocene time span (Muttoni et al. 2000).

The authors gratefully acknowledge O. Lacombe and S. Sliaupa for their constructive criticism of the manuscript. R. Polino and F. Piana are also kindly acknowledged for very useful discussions, A. d'Atri for fundamental help in biostratigraphic dating, Jan Wijbrans for his interest and comments on the earlier version of the manuscript, and G. R. Murrell for the English review. Technical facilities for AMS and NRM analysis were provided by the Universiteit of Utrecht, Paleomagnetic Laboratory, 'Fort Hoofddijk'. The project was financed by grants from the NWO (the Netherland Organization for Scientific Research) and the NSG (Netherlands Research School of Sedimentary Geology; 20020401).

\section{References}

Angelier, J. 1989. From orientation to magnitudes in paleostress determinations using fault slip data. Journal of Structural Geology, 11, 37-50.

BERNINI, M. \& ZeCCA, M. 1990. The deformations in the Oligocene-lower Miocene Molare and Rocchetta Formations. Atti Ticinesi di Scienze della Terra, 33, 1-10.

Bessis, F. 1986. Some remarks on the study of subsidence of sedimentary basins. Application to the Gulf of Lions margin (Western Mediterranean). Marine and Petroleum Geology, 3, 37-63.

Biella, G., Polino, R., De Franco, R., Rossi, P. M., Clari, P., Corsi, A. \& Gelati, R. 1997. The crustal structure of the western Po plain: reconstruction from integrated geological and seismic data. Terra Nova, 9, 28-31.

Boccaletti, M., Coli, M., Eva, C., Ferrari, G., Giglia, G., Lazzarotto, A., Merlanti, F., Nicolich, R., PAPANI, G., Postpischl, D. 1985. Considerations on the seismotectonics of the Northern Apennines. Tectonophysics, 117(1-2), 7-38.

Boccaletti, M., Ciaranfi, N., Cosentino, D., Deiana, G., Gelati, R., Lentini, F., Massari, F., Moratti, G., Pescatore, T., Ricci Lucchi, F. \& TORTORICI, L. 1990. Palinspastic restoration and paleogeographic reconstruction of the peri-Tyrrhenian area during the Neogene. Palaeogeography, Palaeoclimatology, Palaeoecology, 77, 41-50.

Bond, G. C. \& Kominz, M. A. 1984. Construction of tectonic subsidence curves for the early Paleozoic miogeocline, southern Canadian Rocky Mountains: implications for subsidence mechanisms. Geological Society of America Bulletin, 89, 1389-1403.

Bormioli, D. \& LANZA, R. 1995. Rotazioni antiorarie delle rocce terziarie delle Alpi Occidentali e dell'Appennino Settentrionale. In: POLINO, R. \& SACCHI, R. (eds), A. N. Scienze, Atti convegno rapporti Alpi-Appennino, Peveragno, 277-289.

BorRADAILE, G. J. 1988. Magnetic fabrics, petrofabrics and strain. Tectonophysics, 156, 1-20.

Burrus, J. 1984. Contribution to a geodynamic synthesis of the Provençal basin (north-western Mediterranean). Marine Geology, 55, 247-260.

Capponi, G., Crispini, L., Silvestri, R. \& Vigo, E. 1999. The role of Early Miocene trhust tectonics in the structural arrangement of the Voltri Group (Ligurian Alps, Italy): evidence from the Bandita area. Ofioliti, 24(1), 13-19.

Caprara, L., Garzanti, E., Gnaccolini, M. \& MutTI, L. 1985. Shelf-basin transition: sedimentology and petrology of the Tertiary Piedmont Basin (Northern Italy). Rivista Italiana di Paleontologia e Stratigrafia, 90, 545-564.

Carrapa, B., Bertotti, G. \& Wijbrans, J. 2000. Mechanisms involved in the formation of the Tertiary Piemonte Basin in a collisional setting and relations between source area and basin infill from ${ }^{40} \mathrm{Ar} /{ }^{39} \mathrm{Ar}$ dating. European Geophysical Society, (UN)COUPLED 2000, Continental Collision and the Tectonosedimentary Evolution of Forelands: Mechanisms of Coupling and Far-field Deformation, Amsterdam, Czech Geological Society Publisher, 45(3-4), 216. 
Cassano, E., Anelli, L. Fichera, R. \& Cappelli, V. 1986. Pianura Padana, interpretazione integrata di dati geofisici e geologici. In: PIERI, M. \& GROPPI, G. (eds) $73^{\circ}$ Congresso della Societá Geologica Italiana, Roma 1986, 27.

Cazzola, C. \& Rigazio, G. 1982. Sedimentology of Valla and Moglia turbidites, Rochetta Formation (Oligocene-Miocene) of Piedmont Tertiary basin. Giornale di Geologia, 45(1), 87-100.

Cazzola, C. \& Sgavetti, M. 1983. Geometria dei depositi torbiditici della Formazione di Rocchetta e Monesiglio (Oligocene superiore-Miocene inferiore) nell'area compresa tra Spigno e Ceva. Giornale di Geologia, (2) XLV(II), 227-240.

Ciulavu, D. \& Bertotti, G. 1994. The Transylvania Basin and its Upper Cretaceous substratum. Romanian Journal of Tectonics and Regional Geology, 75(2), 59-64.

Clari, P., Dela Pierre, F., Novaretti, A. \& Timpanelli, M. 1995. Late Oligocene-Miocene sedimentary evolution of the critical Alps/ Apennines junction: the Monferrato area, Northwestern Italy. Terra Research, 7, 144-152.

Clark, B. L. 1970. Mechanical formation of preferred orientation in clays. American Journal of Science, 269, 250-266.

Dalla, S., Rossi, M., Orlando, M., Visentin, C., Gelati, R., Gnaccolini, M., Papani, G., Belli, A., Biffi, U. \& Catrullo, D. 1992. Late Eocene-Tortonian tectono-sedimentary evolution in the western part of the Padan basin (northern Italy). Paleontologia Evolucio, 24-25, 341-362.

Dela Pierre, F., Mikhailov, V. \& Polino, R. 1995. The tectonosedimentary evolution of the Tertiary basins in the western Po plain: kinematics inferred from subsidence curves. In: Polino, R. \& SACCHI, R. (eds), A. N. Scienze, Atti Convegno Rapporti Alpi-Appennino, Peveragno, 129-146.

Delvaux, D. 1993. The TENSOR program for paleostress reconstruction:: examples from the east A frican and the Baikal rift zones. EUG VII, 5, abstract supplement 1 to TERRA Nova, Strasbourg, 216.

Duermeijer, C. E., Van Vugt, N., Langereis, C. G., Meulenkamp, J. E. \& Zachariasse, W. J. 1998. A major late Tortonian rotation phase in the Crotone basin using AMS as tectonic tilt correction and timing of the opening of the Tyrrhenian basin. Tectonophysics, 287, 233-249.

Falletti, P., Gelati, R. \& Rogledi, S. 1995. OligoMiocene evolution of Monferrato and Langhe, related to deep structures. In: Polino, R. \& SACCHI, R., A. N. Scienze, Atti Convegno Rapporti AlpiAppennino, Peveragno, 1-19.

Fisher, R. A. 1953. Dispersion on a sphere. Proceedings of the Royal Society of London, A217, 295-305.

Gelati, R. 1968. Stratigrafia dell'Oligo-Miocene delle Langhe tra le valli dei fiumi Tanaro e Bormida di Spigno. Rivista Italiana di Paleontologia e Stratigrafia, 74(3), 865-967.

Gelati, R. \& Gnaccolini, M. 1982. Evoluzione tettonico-sedimentaria della zona limite tra Alpi ed Appennini tra l'inizio dell'Oligocene ed il Miocene medio. Memoria della Società Geologica Italiana, 24, 183-191.
Gelati, R. \& Gnaccolini, M. 1988. Sequenze deposizionali in un bacino episuturale, nella zona di raccordo tra Alpi ed Appennino settentrionale. Atti Ticinesi di Scienze della Terra, 31, 340-350.

Gelati, R. \& Gnaccolini M. 1996. The stratigraphic record of the Oligocene-Early Miocene events at the south-western end of the Piedmont Tertiary Basin. Rivista Italiana di Paleontologia e Stratigrafia, 102(1), 65-76.

Gelati, R. \& Gnaccolini, M. 1998. Synsedimentary tectonics and sedimentation in the Tertiary Piedmont Basin, Northwestern Italy. Rivista Italiana di Paleontologia e Stratigrafia, 104(2), 193-214.

Gelati, R., Gnaccolini, M., Falletti, P. \& CAtrullo, D. 1993. Stratigrafia sequenziale della successione Oligo-Miocenica delle Langhe, Bacino Terziario Ligure-Piemontese. Rivista Italiana di Paleontologia e Stratigrafia, 98(4), 425-452.

Ghibaudo, G., Clari, P. \& Perello, M. 1985. Litostratigrafia, sedimentologia ed evoluzione tettonico-sedimentaria dei depositi miocenici del margine sud-orientale del Bacino Terziario Ligure-Piemontese. Rivista Italiana di Paleontologia e Stratigrafia, 104, 349-397.

Gnaccolini, M. \& Rossi, P. M. 1994. Sequenze deposizionali e composizione delle arenarie nel Bacino Terziario Ligure-Piemontese: osservazioni preliminari. Atti Ticinesi di Scienze della Terra, 37, 3-15.

Gnaccolini, M., Gelati, R., Catrullo, D. \& FAlletti, P. 1990. Sequenze deposizionali nella successione oligo-miocenica delle 'Langhe': un approccio alla stratigrafia sequenziale del Bacino Terziario Ligure-Piemontese. Memoria della Societa Geologica Italiana, 45, 671-686.

Hoogerduijn Strating, E. H. 1994. Extensional faulting in an intraoceanic subduction complexworking hypothesis for the Paleogene of the Alps-Appenine system. Tectonophysics, 238, 255-273.

Hoogerduijn Strating, E. H., Van Wamel, W. A. \& VISSERS, R. L. M. 1991. Some constraints on the kinematics of the Tertiary Piemonte Basin (northwestern Italy). Tectonophysics, 198, 47-51.

Huismans, R. S., Bertotti, G., Ciulavu, D., Sanders, C. A. E., Cloetingh, S. \& Dinu, C. 1997. Structural evolution of the Transylvanian Basin (Romania); a sedimentary basin in the bend zone of the Carpathians. Tectonophysics, 272(2-4), 249-268.

JeLINEK, V. 1978. Statistical processing of anisotropy of magnetic susceptibility on groups of specimens. Studia Geophysics Geodynamics, 22, 50-62.

Jolivet, L., Frizon De Lamotte, D., Mascale, A. \& SÉrAnNE, M. 1999. The Mediterranean basins: Tertiary extension within the Alpine Orogeny-an Introduction. In: DURAND, B., JOLIVET, L., Horváth, F. \& SÉrANne, M. (eds), The Mediterranean Basins: Tertiary extension within the Alpine Orogeny. Geological Society, London, Special Publications, 156, 1-14.

Kissel, C., Barrier, E., LaJ, C. \& Lee, T. Q. 1986. Magnetic fabric in 'undeformed' marine clays from compressional zones. Tectonics, 5, 769-781. 
Laubscher, H. 1991. The arc of the western Alps today. Eclogae Geologica Helvetica, 84(3), 631-659.

LAUBSCHER, H. P. 1992. Jura kinematics and the Molasse Basin. Eclogae Geologica Helvetica, 85, 653-675.

Lee, T., Kissel, C., Laj, C., Horng \& Lue, Y. 1990. Magnetic fabric analysis of the Plio-Pleistocene sedimentary formations of the Coastal Range of Taiwan. Earth and Planetary Science Letters, 98, 23-32.

LoREnZ, C. 1979. L' Oligo-Miocène ligure: un example de transgression. Bulletin de Société geologique de la France, 12(4), 375-378.

LorEnZ, C. 1984. Evolution stratigraphique et structurale des Alpes Ligures depuis l'Eocene superieur. Memoria della Società Geologica Italiana, 28, 211-228.

Matenco, L. \& Bertotti, G., 2000. Tertiary tectonic evolution of the external East Carpathians (Romania). Tectonophysics, 316(3-4), 255-286.

Mattei, M., Sagnotti, L., Facenna, C. \& FuniCELLO, R. 1997. Magnetic fabric of weakly deformed clay-rich sediments in the Italian peninsula: relationship with compressional and extensional tectonics. Tectonophysics, 271, 107-122.

Miletto, M. \& Polino, R. 1992. A gravity model of the crust beneath the Tertiary Piemonte basin (northwest Italy). Tectonophysics, 212, 243-256.

Moore, J. C. \& Geigle, J. E. 1974. Slaty cleavage: incipient occurrences in the deep sea. Science, 183, 509-510.

Mutti, E., Papani, L., Di Biase, D., Davoli, G., Mora, S., Segadelli, S. \& Tinterri, R. 1995. Il Bacino Terziario Epimesoalpino e le sue implicazioni sui rapporti tra Alpi ed Appennino. Memorie di Scienze Geologiche di Padova, 47, 217-244.

Muttoni, G., Lanci, L., Argnani, A., Hirt, A., M., Cibin, U., Abrahamsen, N. \& Lowrie, W. 2000. Paleomagnetic evidence for a Neogene two-phase counterclockwise tectonic rotation in the Northern Apennines (Italy). Tectonophysics, 326, 241-253.

OERTEL, G. 1983. The relationship of strain and preferred orientation of phyllosilicate grains in rocks-a review. Tectonophysics, 100, 413-447.

Peterson, S. R., Hao, Y. \& Oertel, G. 1995. Primary and tectonic intensities in mudrocks. Tectonophysics, 247, 105-119.

PIANA, F. 2000. Structural setting of the Western Monferrato (Alps-Appennines Junction Zone, NW). Tectonics, 19(5), 943-960.

Piana, F. \& Polino, R. 1995. Tertiary structural relationships between Alps and Apennines: the critical Torino Hill and Monferrato area, northwestern Italy. Terra Research, 7, 138-143.

Piana, F., D'Atri, A. \& Orione, P. 1997. The Visone Formation, a marker of the Early Miocene tectonics in the Alto Monferrato Domain (Tertiary Piemonte Basin, NW Italy). Memoria della Società Geologica Italiana, 49, 145-162.
Pieri, M. \& GroppI, G. 1981. Subsurface Geological Structure of the Po Plain, Italy. Progretto Finalizzato Geodinamica, 414, 1-13.

Platt, J. P., Behrmann, J. H., Cunningham, P. C., Dewey, J. F., Helman, M., Parish, M., Shepley, M. G., Wallis, S. \& Weston, P. J. 1989. Kinematics of the Alpine arc and the motion of Adria. Nature, 337, 158-161.

Polino, R., Dal Piaz, V. \& Gosso, G. 1990. Tectonic erosion at the Adria margin and accretionary processes for the Cretaceous orogeny of the Alps. In: Roure, F., Heitzmann, P. \& Polino, R. (eds) Deep Structure of the Alps. Société Geologique de France, Paris, Société Geologique Suisse, Zürich, Società Geologica Italiana, Roma, 345-367.

Rehault, J. P., Boillot, G. \& Mauffret, A. 1985. The Western Mediterranean Basin. In: StAnley, D. J. \& WeZel-Forese, C. (eds), Geological Evolution of the Mediterranean Basin. Springer-Verlag, New York, 101-129.

Roure, F., Polino, R. \& Nicolich, R. 1990. Early Neogene deformation beneath the Po plain: constraints on the post-collisional Alpine evolution. Mémoire de la Société géologique de France, 156, 309-322.

Scheepers, P. J. J. \& Langereis, C. G. 1994. Magnetic fabric of Pleistocene clays from the southern Appennines and its foreland: a magnetic lineation induced after tectonic rotations in the arc. Tectonics, 13(5), 1190-1200.

Schmid, S. M. \& Kissling, E. 2000. The arc of the Western Alps in the light of geophysical data on deep crustal structure. Tectonics, 19, 62-85.

Schumacher, M. E., \& Laubscher, H. P. 1996. 3D crustal architecture of the Alps-Apennines join; a new view on seismic data. Tectonophysics, 260(4), 349-363.

Sclater, J. \& Christie, P. A. F. 1980. Continental stretching: an explanation of the post-midCretaceous subsidence on the central North Sea basin. Journal of Geophysical Research, 85, 37113739.

TARling, D. H. \& HroudA, F. 1993. The magnetic anisotropy of rocks. Chapman and Hall, London.

Thio, H. K. 1988. Magnetotectonics in the Piemont Tertiary Basin. Physics of the Earth and Planetary Interiors, 52, 308-319.

Vanossi, M., Cortesogno, L., Galbiati, G., Messiga, B., Piccardo, G. \& VAnnucci, R. 1984. Geologia delle Alpi Liguri: dati, problemi, ipotesi. Memoria della Società Geologica Italiana, 28, 5-57.

Vanossi, M., Perotti, c. R. \& Seno, S. 1994. The Maritime Alps arc in the Ligurian and Tyrrhenian systems. Tectonophysics, 230, 75-89.

Vigliotti, L. \& Langenheim, V. E. 1995. When did Sardinia stop rotating? New paleomagnetic results. Terra Nova, 7, 424-435. 
